\title{
Fluorinated phenylalanines: synthesis and pharmaceutical applications
}

\author{
Laila F. Awad ${ }^{*}$ and Mohammed Salah Ayoup
}

\author{
Review \\ Address: \\ Chemistry Department, Faculty of Science, Alexandria University, \\ P.O. Box 426, Alexandria, 21321, Egypt \\ Email: \\ Laila F. Awad ${ }^{\star}$ - laila.fathy@yahoo.com; Mohammed Salah Ayoup - \\ mohammedsalahayoup@gmail.com \\ * Corresponding author \\ Keywords: \\ $\alpha$-fluorophenylalanine; $\beta$ - and $\beta, \beta$-difluorophenylalanine; fluorinated \\ phenylalanines; PET; pharmaceuticals application
}

Beilstein J. Org. Chem. 2020, 16, 1022-1050. doi:10.3762/bjoc. 16.91

Received: 25 February 2020

Accepted: 27 April 2020

Published: 15 May 2020

This article is part of the thematic issue "Organo-fluorine chemistry V".

Guest Editor: D. O'Hagan

(C) 2020 Awad and Ayoup; licensee Beilstein-Institut. License and terms: see end of document.

\begin{abstract}
Recent advances in the chemistry of peptides containing fluorinated phenylalanines (Phe) represents a hot topic in drug research over the last few decades. D- or L-fluorinated phenylalanines have had considerable industrial and pharmaceutical applications and they have been expanded also to play an important role as potential enzyme inhibitors as well as therapeutic agents and topography imaging of tumor ecosystems using PET. Incorporation of fluorinated aromatic amino acids into proteins increases their catabolic stability especially in therapeutic proteins and peptide-based vaccines. This review seeks to summarize the different synthetic approaches in the literature to prepare D- or L-fluorinated phenylalanines and their pharmaceutical applications with a focus on published synthetic methods that introduce fluorine into the phenyl, the $\beta$-carbon or the $\alpha$-carbon of D-or L-phenylalanines.
\end{abstract}

\section{Introduction}

Major efforts have been focused on the synthesis of fluorinated organic molecules particularly for drug development. The replacement of hydrogen by fluorine has been used in the development to improve the biophysical and chemical properties of bioactives. Such tuning in properties arises from the small size of fluorine, the next in size to hydrogen. However, the high electronegativity of the fluorine leads to low polarizability and a strong covalent bond to carbon [1-4]. Therefore, the introduction of fluorine into phenylalanine (Phe) can modulate the acidity, basicity, hydrophobicity, geometry, conformation, reac- tivity, and moreover the bioavailability of the analogue [1]. Fluorinated amino acids (FAAs) have considerable industrial and pharmaceutical potential [2]. Also, they have played an important role as enzyme inhibitors as well as therapeutic agents $[3,4]$. Moreover, they modulate the properties of peptides and proteins [5-7], influencing aspects such as protein folding, protein-protein interactions, ribosomal translation, lipophilicity, acidity/basicity, optimal $\mathrm{pH}$, stability, thermal stability, and therapeutic properties [8-10]. This extends to metabolic properties of membrane permeability and reactivity [11-14]. The 
effect of peptide structure and stability has been found to depend on the position and number of fluorine atoms within the amino acid chains [15-17]. Incorporation of fluorinated aromatic amino acids into proteins can increase their shelf life, especially in therapeutic proteins and peptide-based vaccines [18] Enhanced catabolic stability [6] can arise from the role of particular aromatic amino acids in membrane-protein interactions [19]. Furthermore, fluorinated aromatic amino acids can alter enzymatic activity as a result of enhanced protein stability [5] Also fluorinated aromatic amino acids can destabilize II-cation interactions whereas their increased hydrophobicity enhances binding affinity [19]. Moreover, the incorporation of fluorinated amino acids into proteins provides the opportunity for probing structure (by NMR techniques) including protein-protein and protein-ligand interactions and consequently metabolic processes [20,21].

Fluorinated phenylalanines (FPhe) have been incorporated into various proteins and enzymes [22-25] with advantageous biophysical, chemical, and biological properties, and their effect on the stability and activity of peptides in therapeutic vaccines and enzymes has been studied [19,26-33].

In this review we provide an overview for the various syntheses of FPhes and analogues. Five different categories of FPhe are represented and are classified $\mathbf{I}-\mathbf{V}$ according to the position of the fluorine(s) (Figure 1).

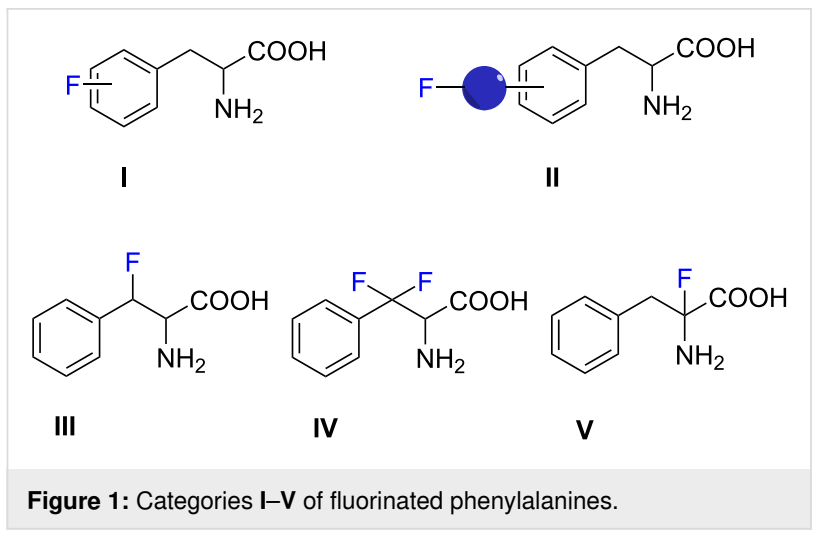

\section{Review \\ 1. Synthesis of fluorinated phenylalanine of type I and II}

Direct attachment of the fluorine atom to the aryl ring of Phe or fluorinated groups directly attached to a spacer extending from the aryl ring constitute types I and II (Figure 1), accordingly we reported herein different methods for their synthesis.

\subsection{Negishi cross coupling of aryl halide and organozinc compounds}

Jackson and co-workers reported the synthesis of a range of phenylalanine derivatives via Negishi cross-coupling reactions of aryl halides and $\mathrm{Zn}$ homoenolates of the protected $(R)$ iodoalanine 2 . The reaction was activated using $\operatorname{Pd}(0)$ as a catalyst.

A palladium-catalyzed cross-coupling reaction between an organozinc iodide and aryl halides offers a convenient method for the direct preparation of protected fluorinated Phe analogues 3. Thus, cross coupling of the protected iodoalanine 2 with 4-fluorobromobenzene (1a) or 2- and 4-fluoroiodobenzene (1b and 1c), respectively, was accomplished using the reported coupling conditions in Scheme 1 to give the $N$-Boc-protected 2- or 4-fluoro-L-phenylalanine esters 3a,b [34,35].

On the other hand, attempted cross-coupling of fluoroiodobenzenes $\mathbf{1 b}$ and $\mathbf{1 c}$ with iodoalanine $\mathbf{2}$ at room temperature using $\mathrm{Pd}_{2}(\mathrm{dba})_{3}(2.5 \mathrm{~mol} \%)$ and SPhos $(5.0 \mathrm{~mol} \%)$ provided excellent yields of $(S)$-phenylalanines $\mathbf{3 a}$ (70\% yield) and $\mathbf{3 b}(80 \%$ yield), respectively. Such an efficiency improvement testifies to the suitability of SPhos as a ligand for these coupling reactions, rather than the less-reactive organozinc reagents [36] (Scheme 1). Decreasing the molar ratio of $\mathrm{Pd}_{2}(\mathrm{dba})_{3} / \mathrm{SPhos}$ to 0.25:0.5 mol \% provided a lower yield of $\mathbf{3 a}(21 \%)$, whereas $\mathbf{3 b}$ showed only a slight decrease in yield (77\%).

The two-inseparable para/meta isomers of all-cis-2,3,5,6-tetrafluorocyclohexylphenyliodide $\mathbf{4}$ and $\mathbf{5}$ were subjected to Jackson's methodology for the synthesis of the appropriate
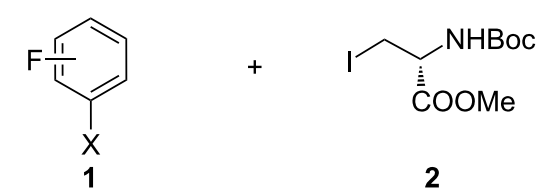

1

2

\author{
$\mathrm{Zn}(5 \mathrm{~mol} \%), \mathrm{Pd}(\mathrm{OAc})_{2}(10 \mathrm{~mol} \%)$ \\ $\mathrm{P}(\mathrm{o}-\mathrm{Tol})_{3}$, DMF, $2 \mathrm{~h}, 40 \%$ \\ or $\mathrm{Pd}\left(\mathrm{Pt}-\mathrm{Bu}_{3}\right)_{2}(1.25 \mathrm{~mol} \%)$ \\ $\mathrm{DMF}, 50^{\circ} \mathrm{C}, 16 \mathrm{~h}$
}

1a $\mathrm{X}=\mathrm{Br}, 4-\mathrm{F}$

1b $X=1,2-F$

1c $X=1,4-F$

Scheme 1: Synthesis of fluorinated phenylalanines via Jackson's method. 
amino acid products. Thus, the coupling of the zinc homoenolate of $(R)$-iodoalanine $\mathbf{2}$ with a mixture of $\mathbf{4}$ and $\mathbf{5}$ in the presence of $\mathrm{Pd}(\mathrm{dba})_{3}$ and SPhos resulted in an excellent conversion to the fully protected amino acid isomers 6 and 7 , which were readily separated from each other by chromatography. Deprotection of isomers $\mathbf{6}$ and $\mathbf{7}$ gave the individual free amino acids $p$-(S)-8 and $m-(S)-\mathbf{9}[37,38]$ (Scheme 2).

Coupling of one molar equivalent of neopentyl sulfonate ester 10a or trichloroethyl ester 10b with two molar equivalents of the zincate of Fmoc-3-iodo-L-alanine methyl ester 11, to form the protected L-4-[sulfono(difluoromethyl)]phenylalanines 12a and $\mathbf{1 2 b}$, was carried out using $5 \mathrm{~mol} \%\left(\mathrm{PPh}_{3}\right)_{2} \mathrm{PdCl}_{2}$ and
$10 \mathrm{~mol} \%$ DIBAL in THF/DMAC $1: 1$ at $65-70{ }^{\circ} \mathrm{C}$ for $6 \mathrm{~h}$. Partial deprotection by alkaline hydrolysis of $\mathbf{1 2 a}$ and $\mathbf{1 2 b}$ afforded L-4-[sulfono(difluoromethyl)]phenylalanine derivatives 13a and 13b, respectively [39] (Scheme 3).

\subsection{Alkylations of fluorinated aryl halides with a chiral auxiliary}

Alternatively, the coupling of the bis(dimethoxybenzyl)-protected sulfonamide 14, instead of the esters $10 \mathrm{a}$ and $\mathbf{1 0 b}$ with zincate $\mathbf{1 1}$ using a variety of catalysts and different reaction conditions, was unsuccessful. However, coupling of 4-[bis(dimethoxybenzyl)difluoromethyl]benzyl bromide (14) with the lithium enolate of William`s lactone $\mathbf{1 5}$ gave the pro-<smiles>[3H]c1ccc([C@@H]2[C@H](F)[C@H](F)C[C@@H](F)[C@@H]2F)cc1</smiles><smiles>FC1CC(F)C(F)C(c2cccc(I)c2)C1F</smiles>

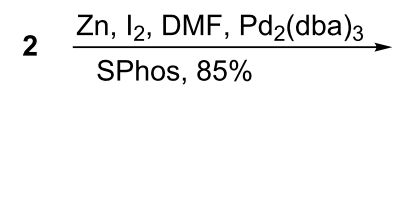<smiles>[R6]NC(Cc1ccc(C2C(F)C(F)CC(F)C2F)cc1)OC(C)=O</smiles>

6<smiles>N[C@H](Cc1ccc(C2C(F)C(F)CC(F)C2F)cc1)C(=O)O</smiles>

8, $100 \%$<smiles>CC(=O)C(Cc1cccc(C(F)(F)F)c1)NC(=O)OCc1ccccc1</smiles><smiles>N[C@@H](Cc1cccc(C2C(F)C(F)CC(F)C2F)c1)C(=O)O[Mg]</smiles>

Scheme 2: Synthesis of all-cis-tetrafluorocyclohexylphenylalanines.<smiles>[R]OS(=O)(=O)C(F)(F)c1ccc(I)cc1</smiles>

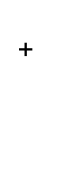

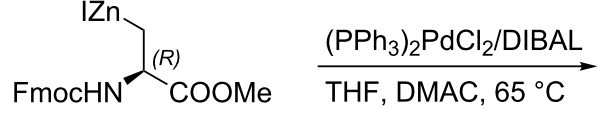

11<smiles>[R]OC(=O)C(Cc1ccc(C(F)(F)S(=O)(=O)O[R])cc1)NC(=O)O</smiles><smiles>[C-]#[Co+]OC(=O)O</smiles><smiles>[R]OS(=O)(=O)C(F)(F)c1ccc(CC(=NC(=O)O)C(=O)O)cc1</smiles>

12a $\mathrm{R}=\mathrm{nPt}$ 12b $R=$ TCE 13a $\mathrm{R}=\mathrm{nPt}$ 13b $R=T C E$ 
tected amino acid $\mathbf{1 6}$ in $80 \%$ yield. The desired protected amino acid 17 was readily obtained after reduction of 16 using $\mathrm{PdCl}_{2}$ as a catalyst, followed by treating the product with Fmoc-OSu in dioxane/aq $\mathrm{Na}_{2} \mathrm{CO}_{3}$ (99\%, two steps) [40] as illustrated in Scheme 4.

The reaction of aminomalonate $\mathbf{1 8}$ with fluorinated benzyl bromides 19a-c afforded the corresponding aralkyl diesters 20a-c. Partial hydrolysis followed by decarboxylation gave the $N$-benzyloxycarbonyl DL-amino acid esters 22a-c, which upon enzymatic hydrolysis of the ester group using the subtilisin-type Carlsberg enzyme led to D-amino acid esters 23a-c and the corresponding Cbz-protected $p, m$-fluoro-, or pentafluoro-L-phenylalanine derivatives $\mathbf{2 4 a - c}$, respectively [41] (Scheme 5).
The stereoselective benzylation of $(S)$-imidazolidinone $((S)$ Boc-BMI) 25 with tetrafluorobenzyl bromides 26a,b afforded the benzylated imidazolidinones $\mathbf{2 7 a}, \mathbf{b}$. The acidic hydrolysis of $\mathbf{2 7} \mathbf{a}, \mathbf{b}$ with simultaneous deprotection to release the free amines gave amides 28a,b. Treatment of the latter with aqueous potassium hydroxide finally afforded $(S)$-2-amino-3-(2,3,4,5-tetrafluorophenyl)propionic acid (29a) and (S)-2-amino-3-(2,3,5,6tetrafluorophenyl)propionic acid (29b) [42] (Scheme 6).

Alternatively, phenylalanines 29a,b were also synthesized by alkylation of 26a,b with the chiral auxiliary 31, which was obtained by reaction of the cyclic dipeptide $\mathbf{3 0}$ with triethyloxonium tetrafluoroborate. The alkylation reaction of $\mathbf{2 6 a}, \mathbf{b}$ was carried out with $n$-BuLi in THF at $-78{ }^{\circ} \mathrm{C}$ to give 32a,b. Acid hydrolysis of the alkylated product $\mathbf{3 2} \mathbf{a}, \mathbf{b}$ afforded the ethyl<smiles>CCCCN(CCCC)S(=O)(=O)C(F)(F)c1ccc(CBr)cc1</smiles><smiles>O=C1CN(C(=O)OCc2ccccc2)C(c2ccccc2)[C@H](c2ccccc2)O1</smiles>

\section{$\underset{\text { THF/HMPA }}{\stackrel{\text { LiHMDS }}{\longrightarrow}}$} $-78^{\circ} \mathrm{C}$<smiles>CCCCN(C)S(=O)(=O)C(F)(F)c1ccc(C[C@H]2C(=O)O[C@@H](c3ccccc3)C(c3ccccc3)N2C(=O)OCc2ccccc2)cc1</smiles>

16

$$
\frac{\text { 1. } \mathrm{PdCl}_{2}, \mathrm{H}_{2}, \mathrm{EtOH}}{\begin{array}{l}
\text { 2. } \mathrm{Na}_{2} \mathrm{CO}_{3}, \mathrm{Fmoc}-\mathrm{OSu} \\
\text { dioxane } / \mathrm{H}_{2} \mathrm{O}, 0{ }^{\circ} \mathrm{C}
\end{array}}
$$<smiles>CCCCNC(Cc1ccc(C(F)(F)F)cc1)C(=O)O</smiles>

$17,99 \%$

Scheme 4: Synthesis of L-4-[sulfono(difluoromethyl)]phenylalanine derivatives 17

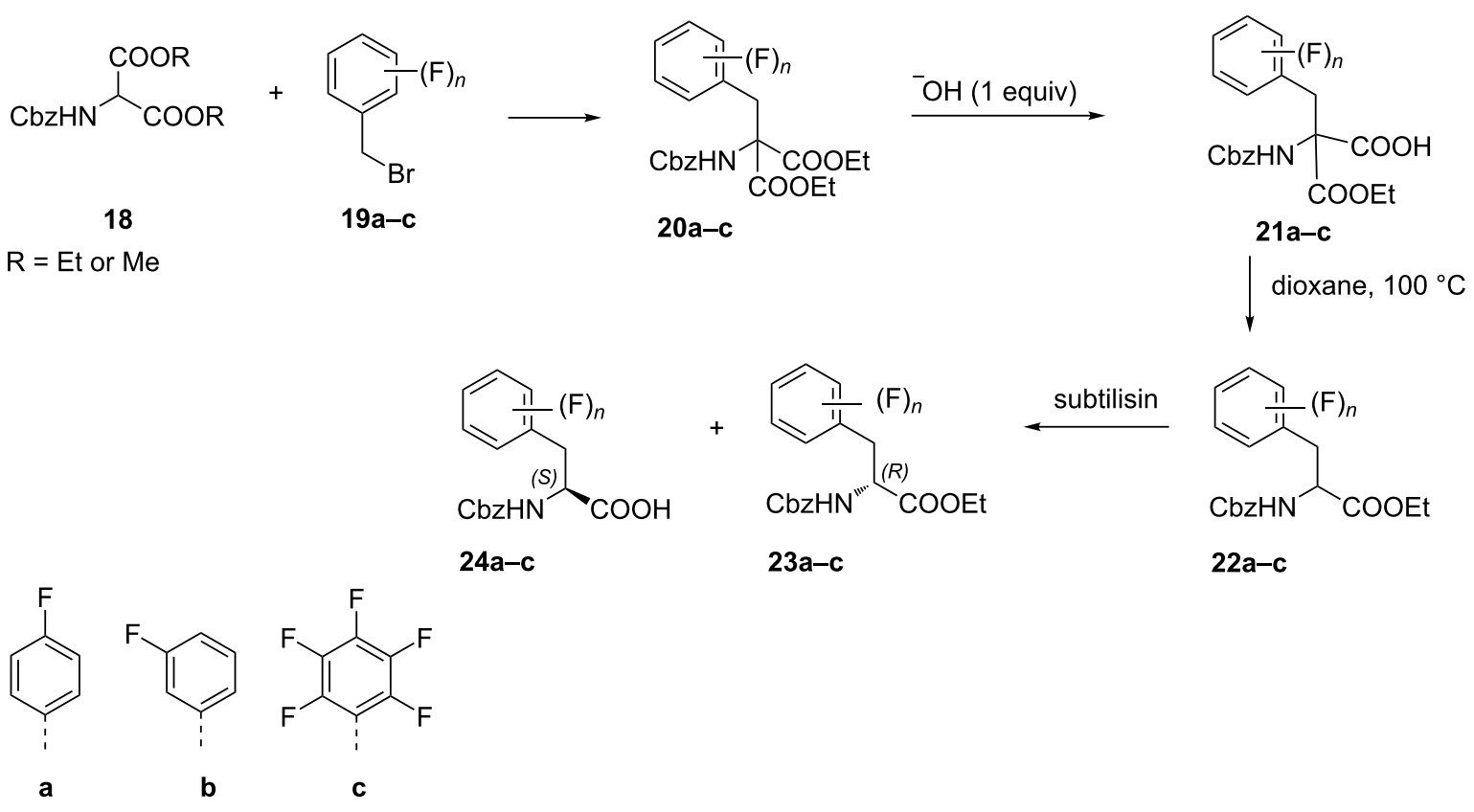




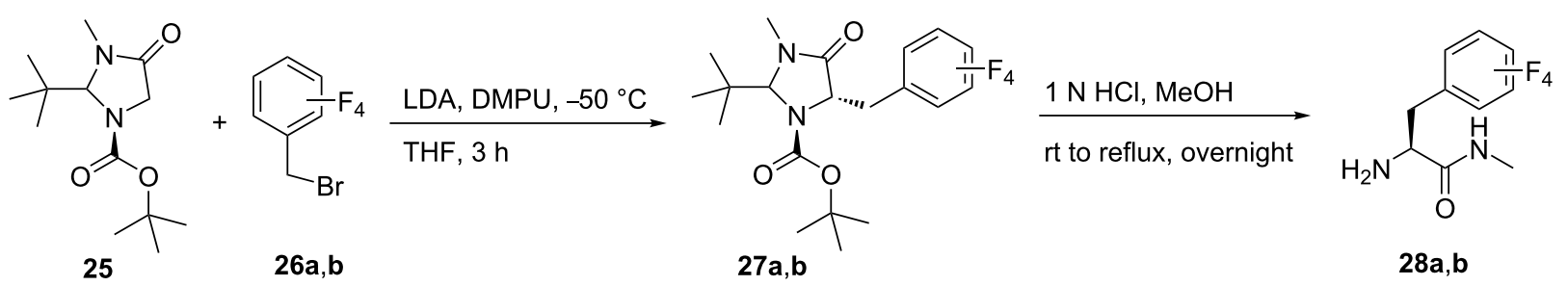<smiles>Fc1cc(F)c(F)c(F)c1F</smiles><smiles>Fc1cc(F)c(F)c(I)c1F</smiles>

b
$2 \mathrm{~N} \mathrm{KOH}$, reflux, $2.5 \mathrm{~h}$<smiles>NC(Cc1ccc(F)cc1)C(=O)O</smiles>

29a,b

Scheme 6: Synthesis of tetrafluorophenylalanine analogues via the 3-methyl-4-imidazolidinone auxiliary 25.

esters of tetrafluorophenylalanine 33a, $\mathbf{b}$, which by alkaline hydrolysis afforded the tetrafluoro derivatives $29 \mathrm{a}$ and $\mathbf{2 9 b}$, respectively [43] (Scheme 7).

The syntheses of $(R)$-38a and $(R)-\mathbf{3 8} \mathbf{b}$ were carried out by alkylation of the Schöllkopf reagent $((2 S)-(+)-2,5$-dihydro-3,6dimethoxy-2-isopropylpyrazine, 34) with the corresponding fluorinated benzyl bromides 35a,b via intermediates 36a,b. The alkylation products were then hydrolyzed to generate the amino acid esters which were directly Boc protected to give the
$N$-Boc-protected amino acid methyl esters $37 \mathbf{a}, \mathbf{b}$. Finally, ester hydrolysis afforded the useful Boc- $(R)$-amino acids 38a,b [44] (Scheme 8).

A one-pot double alkylation of the chiral auxiliary 39 with benzyl iodides 40a,b gave cis-dialkyl derivatives 41a,b in $70-72 \%$ yield. The subsequent removal of the auxiliary followed by treatment with Fmoc-OSu gave the $N$-protected 2-fluoro- and 2,6-difluorophenylalanine derivatives $\mathbf{4 2 a}, \mathbf{b}$ in quantitative yields [45] (Scheme 9).<smiles>CCOC(=O)C(C)OCC</smiles>
30<smiles>CCOC1=NC(C(C)C)C(OCC)=NC1</smiles>

31

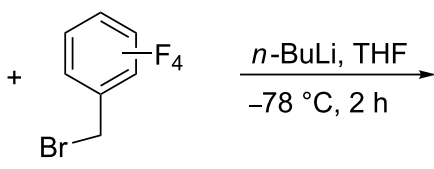

26a,b<smiles>CCOC1=N[C@H](Cc2cccc[Y]2F)C(OCC)=NC1C(C)C</smiles>

$32 a, b$<smiles>Fc1cc(F)c(F)c(F)c1F</smiles>

a<smiles>Fc1cc(F)c(F)c(I)c1F</smiles>

b<smiles>N[C@@H](Cc1ccc(F)cc1)C(=O)O</smiles>

29a,b<smiles></smiles>

$50{ }^{\circ} \mathrm{C}, 2 \mathrm{~h}$<smiles>CCOC(=O)C(N)Cc1ccc(F)cc1</smiles>

$33 a, b$ 

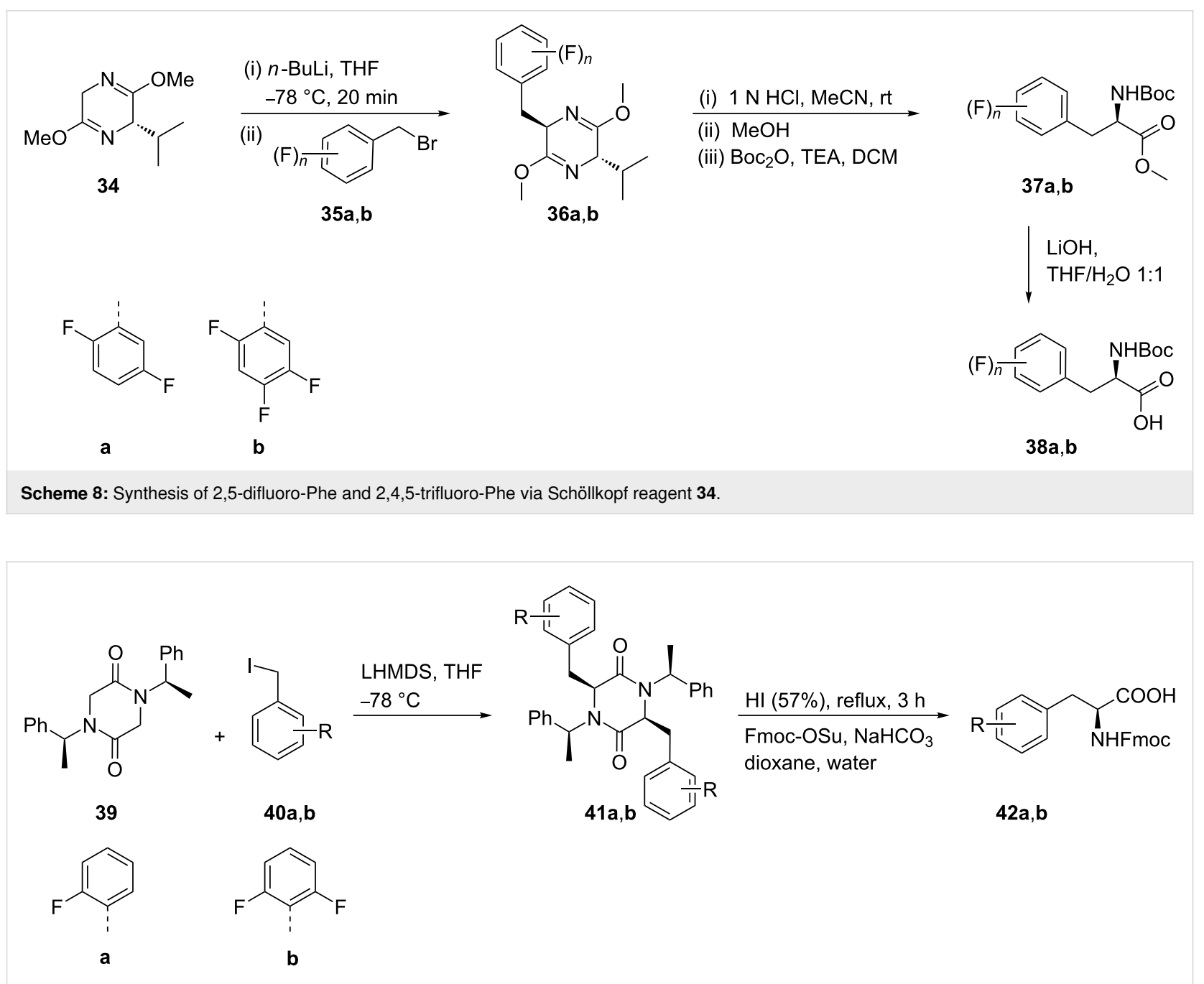

Scheme 9: Synthesis of 2-fluoro- and 2,6-difluoro Fmoc-Phe derivatives starting from chiral auxiliary 39.

The radiolabeled 2-[ $\left.{ }^{18} \mathrm{~F}\right]$-fluoro-L-phenylalanine 46 was synthesized as a promising radiopharmaceutical agent for molecular imaging by positron emission tomography (PET). The threestep synthesis of $\mathbf{4 6}$ started from $\left[{ }^{18} \mathrm{~F}\right]$-fluoride exchange in $\mathbf{4 3}$ to generate 44. The isotope exchange was explored by using $\left[{ }^{18} \mathrm{~F}\right]-\mathrm{TBA}$ in DMF at $130{ }^{\circ} \mathrm{C}$ for $10 \mathrm{~min}$ to give $\left[{ }^{18} \mathrm{~F}\right]-\mathbf{4 4}$. Decarbonylation of $\mathbf{4 4}$ was achieved by treatment with $\mathrm{Rh}\left(\mathrm{PPh}_{3}\right)_{3} \mathrm{Cl}$ to afford 45 and the subsequent removal of protecting groups gave 46 . Conventional reactions yielded the desired product 2-[ $\left.{ }^{18} \mathrm{~F}\right] \mathrm{FPhe} \mathbf{4 6}$ in $43 \%$ yield, whereas under microwave irradiation a $34 \%$ yield was obtained. Under the optimized conditions, the enantiomeric purity was reported to be $\geq 94 \%$ ee [46] (Scheme 10).

\subsection{Photooxidative cyanation of fluorinated benzylamine}

A convenient, protecting group-free, and semicontinuous process was reported for the synthesis of racemic fluorinated phenylalanine $\cdot \mathrm{HCl}$ starting from benzylamines $47 \mathbf{a}-\mathbf{c}$. Thus, a singlet oxygen-driven photooxidative cyanation of amines 47a-c using tetraphenylporphyrin (Tpp), followed by an acidmediated hydrolysis of the intermediate fluorinated $\alpha$-amino nitrile 48a with $30 \% \mathrm{HCl}$ aq/acetic acid, gave the 4-fluorophenylalanine $\cdot \mathrm{HCl} 49 \mathrm{a}$ in a good overall yield (67\%) [47] (Scheme 11).

\subsection{Hydrolysis of Erlenmeyer's azalactone}

A multistep Erlenmeyer azalactone synthesis was reported as an important method for the synthesis of fluorinated $\alpha$-amino acids 53a-h. Thus, a three-component condensation of a series of fluorinated benzaldehydes 50a-h, $N$-acetyl- or $N$-benzoylglycine 51a or 51b, respectively, and an excess of acetic anhydride in the presence of sodium acetate afforded the oxazolones 52a-h. The subsequent reductive ring cleavage of 52a-h without isolation, was carried out with red phosphorus in hydroiodic acid to give the fluorinated phenyl- 


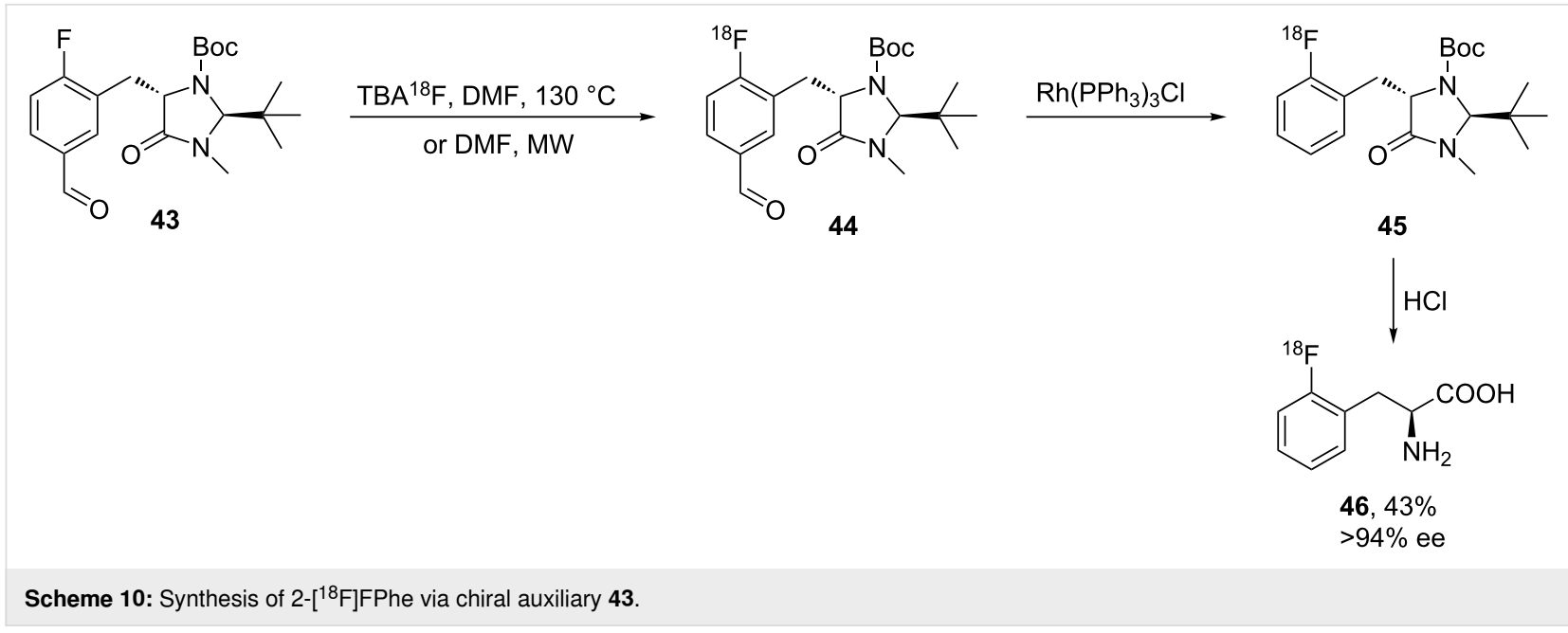

flow $\left(\tau_{\text {res }}=4 \mathrm{~min}\right)$
$\begin{aligned} & \mathbf{a} \mathrm{X}=4-\mathrm{F} \\ & \mathbf{b X}=3-\mathrm{F} \\ & \mathbf{c X}=2-\mathrm{F}\end{aligned}$
Scheme 11: Synthesis of FPhe 49a via photooxidative cyanation.

alanine analogues 53a-h. Alternatively, a two-step sequence to generate amino acids $\mathbf{5 3} \mathbf{a}-\mathbf{h}$ was attempted by first hydrolysis of $\mathbf{5 2} \mathbf{a}-\mathbf{h}$ to form acids $\mathbf{5 4 a - h}$ which then were reduced with $\mathrm{P} / \mathrm{HI}$ to the desired products 53a-h [48]. The free amino acid 53i was prepared by the same protocol [49] (Scheme 12).

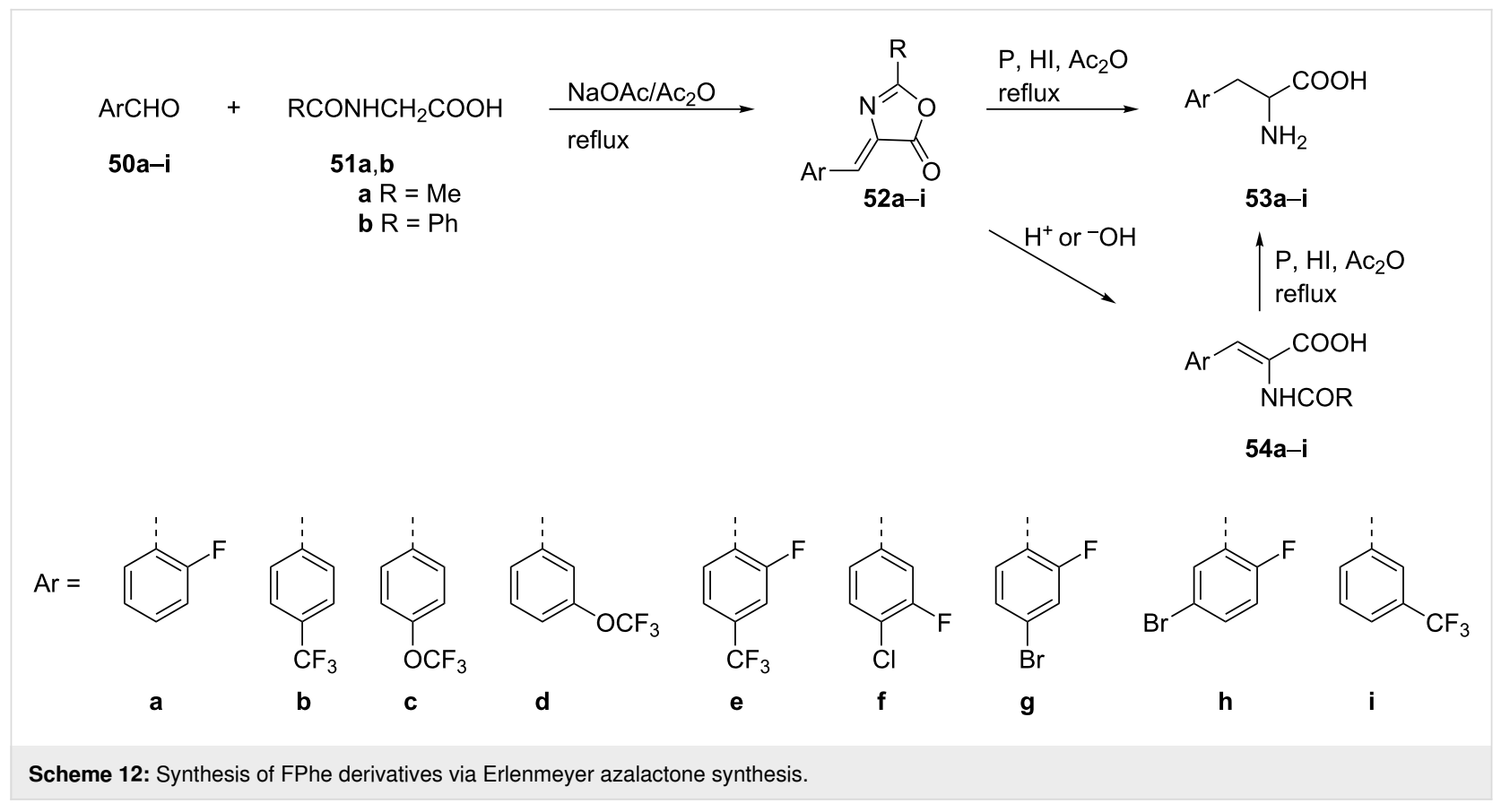


2,5-Difluorophenylalanines with either $R$ or $S$ configuration were synthesized also via the Erlenmeyer azalactone method. The synthesis started with the multicomponent reaction of aldehyde 55, acetylglycine 51a and acetic anhydride to give the azalactone 56. The subsequent basic hydrolysis of $\mathbf{5 6}$ gave $\mathbf{5 7}$ that, on catalytic hydrogenation, afforded racemic difluorinated Phe 58. The isomers were separated by selective hydrolysis using a protease from Bacillius sp to generate the $(S)$ - $N$-acetyl acid 59 with $>99.5 \%$ ee and the corresponding $(R)$ - $N$-acetyl ester 60 with $>99.5 \%$ ee [50] (Scheme 13).

The synthesis of 3-bromo-4-fluoro-( $S)$-Phe $(\mathbf{6 5})$ was carried out by reacting 3-bromo-4-fluorobenzaldehyde (61) and $\mathrm{N}$-acetylglycine (51a) to provide intermediate 63 in high yield and without purification. Then, the transition-metal-catalyzed asym- metric hydrogenation of the $\alpha$-amidocinnamic acid 63 using the less frequently used ferrocene-based ligand $\mathrm{Me}-\mathrm{BoPhoz}$ led to the $N$-acetyl-L-phenylalanine derivative 64 with complete conversion and with $94 \%$ ee. The desired enantiomer $(S)-65$ was obtained as a single isomer ( $>99 \%$ ee) after selective enzymatic hydrolysis of $\mathbf{6 4}$ using an acylase under mild conditions (pH 8.0, $40{ }^{\circ} \mathrm{C}, 4 \mathrm{~d}$, with $\mathrm{CoCl}_{2}$ as co-factor) [51] (Scheme 14).

\subsection{Direct radiofluorination of L-phenylalanine}

The direct radiofluorination of L-phenylalanine (66) with either $\left[{ }^{18} \mathrm{~F}\right] \mathrm{F}_{2}$ or $\left[{ }^{18} \mathrm{~F}\right] \mathrm{AcOF}$ in trifluoroacetic acid (TFA) afforded the three isomeric $o, m$, and $p$-fluoro-L-phenylalanines 46,67 , and 68, in ratio 72.5:13.9:13.6, respectively. In this reaction, $\left[{ }^{18} \mathrm{~F}\right] \mathrm{AcOF}$ showed a higher regioselectivity and less side product formation compared with $\left[{ }^{18} \mathrm{~F}^{\mathrm{F}} \mathrm{F}_{2}[52]\right.$ (Scheme 15).<smiles>C=Cc1cc(F)ccc1F</smiles>

55<smiles>NCC(=O)O</smiles>

$51 \mathrm{a}$

\section{$\mathrm{Ac}_{2} \mathrm{O} / \mathrm{NaOAc}$}

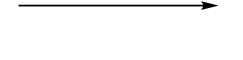<smiles>CC1=N/C(=C\c2cc(F)ccc2F)C(=O)O1</smiles>

56

\section{$\mathrm{NaOCH}_{3} / \mathrm{CH}_{3} \mathrm{OH}$}

protease from Bacillius $s p$<smiles>CC(=O)N[C@@H](Cc1cc(F)ccc1F)C(C)=O</smiles>

$60,49 \%$ $>99.5 \%$ ee<smiles>C=CC(Cc1cc(F)ccc1F)C(=O)O</smiles>

$59,57 \%$<smiles>COC(=O)/C(=C/c1cc(F)ccc1F)NC(C)(F)F</smiles>

57

$\mathrm{pH} 7.5$<smiles>CC(=O)N[C@@H](Cc1cc(F)ccc1F)C(C)=O</smiles>

58<smiles>CC(=O)NCC(=O)ONC(=O)OCC1CCCCC1</smiles>

61

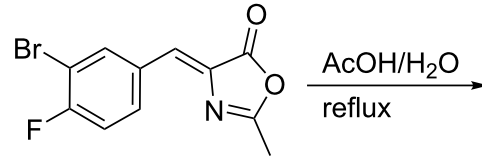

62<smiles>CC(=O)NC(=Cc1ccc(F)c(Br)c1)C(=O)O</smiles>

63<smiles>N[C](Cc1ccc(F)c(Br)c1)C(=O)O</smiles>

65, $67 \%$ $>99 \%$ ee
$\mathrm{H}_{2}$ (30 psi), $\mathrm{MeOH}, \mathrm{rt}, 24 \mathrm{~h}$ $\mathrm{Rh}(\mathrm{COD})_{2} \mathrm{OTf}(0.15 \mathrm{~mol} \%)$ $R$-Me-BoPhoz (0.18 mol \%)

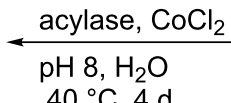

$40^{\circ} \mathrm{C}, 4 \mathrm{~d}$<smiles>CCNC(Cc1ccc(F)c(Br)c1)C(=O)O</smiles>

64, $85 \%$ $>94 \%$ ee 


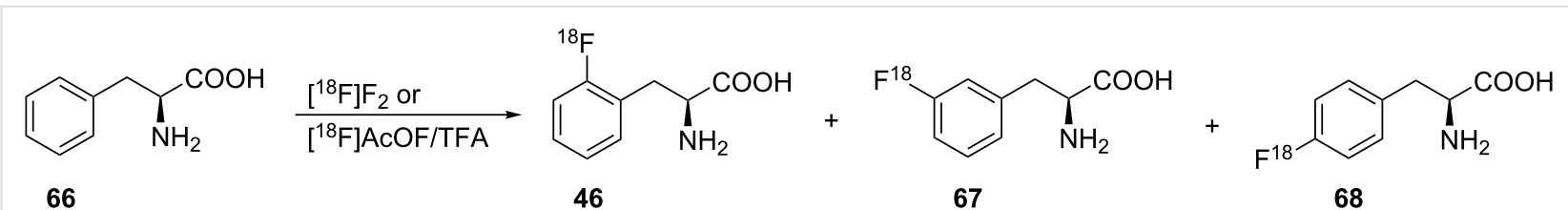

Scheme 15: Synthesis of $\left[{ }^{18} \mathrm{~F}\right] \mathrm{FPhe}$ via radiofluorination of phenylalanine with $\left[{ }^{18} \mathrm{~F}\right] \mathrm{F}_{2}$ or $\left[{ }^{18} \mathrm{~F}\right] \mathrm{AcOF}$.

The radiolabeled compound, 4-borono-2-[ $\left.{ }^{18} \mathrm{~F}\right]$ fluoro-L-phenylalanine (70) was prepared by direct fluorination of 4-borono-Lphenylalanine (BPA, 69) with $\left[{ }^{18} \mathrm{~F}\right] \mathrm{AcOF}$ or $\left[{ }^{18} \mathrm{~F}\right] \mathrm{F}_{2}$. The reaction was followed by a HPLC separation using a Delta-Pak $\mathrm{Cl} 8$ cartridge $0.1 \%$ acetic acid as the mobile phase at a flow rate of $10 \mathrm{~mL} / \mathrm{min}$. The product was isolated in radiochemical yields of $25-35 \%$ and with a radiochemical purity of more than $99 \%$. The ${ }^{18} \mathrm{~F}$-labeling of 4-borono-D,L-phenylalanine (BPA) provided a potential tool for cancer treatment by boron neutron capture therapy [53] (Scheme 16).

The syntheses of a variety of clinically relevant radiotracers including protected 4-[ $\left.{ }^{18} \mathrm{~F}\right]$ fluorophenylalanines 72a,b [54] were achieved by a copper-mediated nucleophilic radiofluorination of arylstannanes 71a,b with $\left[{ }^{18} \mathrm{~F}\right] \mathrm{KF}$ (Scheme 17).

\subsection{Alkylation of benzophenone imine of glycine ester}

Pentafluoro-L-phenylalanine (77a) and 2,4-ditrifluoromethyl-Lphenylalanine (77b) were synthesized through alkylation of the benzophenone imine of glycine ester $\mathbf{7 3}$, with perfluorinated benzylbromide 19c or 2,4-bis(trifluoromethyl)benzyl bromide (74) in the presence of 2,7-bis $[O(9)$-allylhydrocinchonidinium$\mathrm{N}$-methyl]naphthalene dibromide, to afford the fluorinated phenylalanine imines $\mathbf{7 5 a}, \mathbf{b}$ with ees $<98 \%$. The products were hydrolyzed and deprotected in a two-step protocol to afford the desired products 77a,b [55] (Scheme 18).

Interestingly substitution of Phe by either $\mathbf{7 7 b}$ or $\mathbf{7 7 a}$ in the proteasome inhibitors bortezomib or epoxymicin, led to an increase in the efficiency as anticancer proteasome inhibitors. The fluorinated amino acids $\mathbf{7 7} \mathbf{a}$ and $\mathbf{7 7} \mathbf{b}$ were used mainly for two reasons, i.e., the ready availability and hydrophobicity [55].

Further, $(S)$-pentafluorophenylalanine (Pff, 77a) was used to stabilize proteins for potential applications in various proteinbased biotechnologies. To improve protein stability, natural hydrocarbon amino acids were replaced with Pff 77a. The effect of enhanced protein stability upon this replacement is referred as to 'fluoro-stabilization effect' [56].

\subsection{Knoevenagel condensation of methyl isocyanoacetate}

Three isomers of fluorinated phenylalanines 53a,b and $\mathbf{8 1}$ were synthesized by Knoevenagel condensation of methyl isocyanoacetate (79) and the corresponding fluorinated benzaldehyde derivatives $\mathbf{5 0 a}, \mathbf{b}$, and $m$-fluorobenzaldehyde (78) as electrophiles in the presence of catalytic amounts of $\mathrm{Cu}(\mathrm{I})$ and base. The cinnamate derivatives $\mathbf{8 0 a - c}$ obtained were hydrogenated either under homogeneous or heterogeneous conditions fol-<smiles>N[C](Cc1ccc(B(O)O)cc1)C(=O)O</smiles>

69

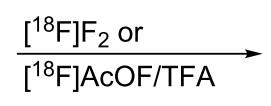

in<smiles>N[C@@H](Cc1ccc(B(O)O)cc1[18F])C(=O)O</smiles>

70, RCY $25-35 \%$

Scheme 16: Synthesis of 4-borono-2-[ $\left.{ }^{18} \mathrm{~F}\right] \mathrm{FPhe}$.

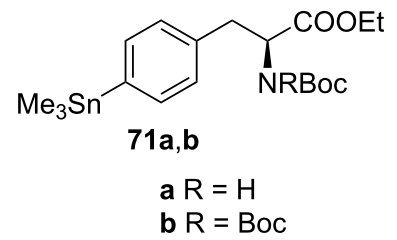

$\frac{\mathrm{Cu}(\mathrm{OTf})_{2} \text { (2 equiv), pyridine (15 equiv) }}{\left[{ }^{18} \mathrm{~F}\right] \mathrm{KF}, \mathrm{DMA}(0.01 \mathrm{M}), 140^{\circ} \mathrm{C}, 5-30 \mathrm{~min}}$<smiles>CCOC(=O)NC(Cc1ccc(F)cc1)C(=O)NCc1ccccc1</smiles>

$72 \mathbf{a}, \mathbf{b}$ 


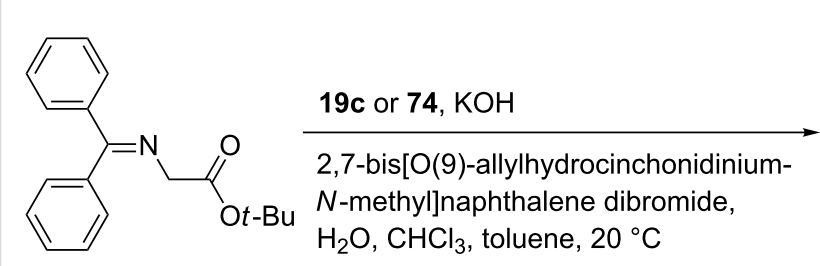

73<smiles>Cc1cccc(F)c1F</smiles>

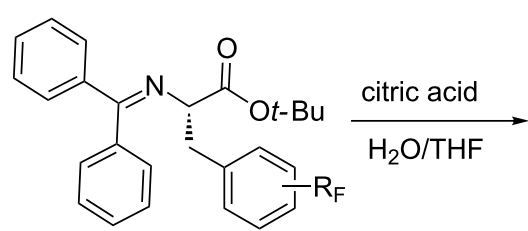

$75 a, b$

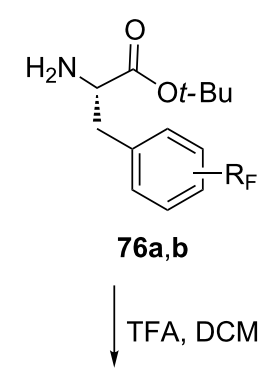<smiles>[NH3+][C@@H](Cc1ccc(F)cc1)C(=O)[O-]</smiles>

$77 a, b$

Scheme 18: Synthesis of FPhe derivatives via intermediate imine formation.

lowed by deprotection of both the amide and the ester moieties to give the racemic fluorinated phenylalanines 53a,b, or $m$-fluorophenylalanine (81) with good yields [57] (Scheme 19).

\subsection{Coupling of $N$-hydroxytetrachlorophthalimide esters with boronic acids}

4-(2-Fluoroethyl)-L-phenylalanine and 3-(2-fluoroethyl)-Lphenylalanine $(\mathbf{8 8 a}, \mathbf{b})$, respectively, were synthesized starting from partially protected L- or D-aspartic acid derivatives $\mathbf{8 2}$ which were activated as the $N$-hydroxytetrachlorophthalimide esters 83. The treatment of the esters $\mathbf{8 3}$ with boronic acids $\mathbf{8 4 a}, \mathbf{b}$ afforded the substituted phenylalanine derivatives $\mathbf{8 5 a}, \mathbf{b}$, respectively [58]. Deprotection of the hydroxy group was achieved by treatment with TBAF in THF to give $\mathbf{8 6 a}, \mathbf{b}$. Finally, fluorination of the alcohols 86a,b with DAST followed by deprotection gave the targeted compounds $\mathbf{8 8 a}, \mathbf{b}$ (Scheme 20).

Cross-coupling reactions with boronic acids were found to be successful only for the synthesis of para and meta-deriva- tives. Several attempts were made to prepare the ortho-substituted derivatives $\mathbf{9 3}$ and $\mathbf{9 5}$. The synthesis of D,L-93 or L-95 was achieved by vinylation of the protected D, L-N-Boc-2bromophenylalanine $(\mathbf{8 9})$ using a Stille coupling reaction to give the $\boldsymbol{o}$-vinyl derivative $\mathbf{9 0}$ as key intermediate. A hydroboration reaction of compound $\mathbf{9 0}$ afforded the primary alcohol 91, which was directly fluorinated and deprotected to give the free amino acids 93 (D and L). Alternatively, alcohol 91 was activated by tosylation to give 94 as a precursor for radiofluorination that was achieved to give 2- $\left[{ }^{18} \mathrm{~F}\right]$ FELP L-95 using $\left[{ }^{18} \mathrm{~F}\right]-$ fluoride complexed with Kryptofix ${ }^{\circledR} / \mathrm{K}^{+}$followed by deprotection with $\mathrm{HCl}$ and purification. This product emerged as promising new PET tracer for brain tumor imaging [58] (Scheme 21).

\subsection{Alkylation and hydrolysis of $\mathrm{Ni}(\mathrm{II})$ or $\mathrm{Zn}(\mathrm{II})$ complexes}

The synthesis of a series of fluorinated phenylalanines was achieved by transamination reactions between $(R)$ or $(S)$ - (15aminomethyl-14-hydroxy-5,5-dimethyl-2,8-dithia[9](2,5)pyr-

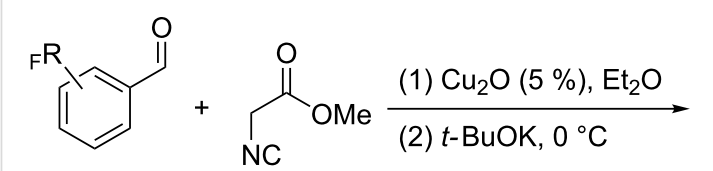

$50 a, b$ and 78
79<smiles>Cc1ccccc1F</smiles>

a<smiles>FC(F)(F)c1ccc(I)cc1</smiles>

b<smiles>COC(=O)/C(=C/c1ccccc1)NC(=O)O</smiles>

$80 a-c$
(1) $\mathrm{H}_{2}, \mathrm{Pd} / \mathrm{C}, \mathrm{MeOH}$

(2) $\mathrm{HCl}, \mathrm{MeOH}$

(3) $\mathrm{LiOH}, \mathrm{MeCN}, \mathrm{H}_{2} \mathrm{O}$<smiles>NC(Cc1c[R]ccc1)C(=O)O</smiles>

$53 a, b$, and $81\left(R_{F}=c\right)$ 
$\overbrace{\text { * }}^{\text {NHBoc }}<\frac{\text { TCNHPI, DIC }}{D C M, r t}$

82<smiles>CC(C)(C)OC(=O)CC(NC(=O)ON1C(=O)c2c(Cl)c(Cl)c(Cl)c(Cl)c2C1=O)C(=O)c1ccccc1</smiles>

83
$\mathrm{NiCl}_{2} \cdot 6 \mathrm{H}_{2} \mathrm{O}$, BBBPY,

$\mathrm{Et}_{3} \mathrm{~N}, \mathrm{DMF} /$ dioxane 1:10

$75^{\circ} \mathrm{C}$, overnight<smiles>CC(C)(C)CCc1ccc(CC(C)(C)C)cc1</smiles>

84a,b OTBS

$1 \mathrm{M}$ TBAF

THF/THF, rt<smiles>NC(Cc1ccccc1)C(=O)O</smiles>

88a,b
TFA/DCM 1:1, rt<smiles>CC(C)(C)OC(=O)C(=Cc1ccccc1)NC(=O)OCc1ccccc1</smiles>

DAST, DCM, $0{ }^{\circ} \mathrm{C}$ to rt<smiles>CC(C)(C)OC(=O)C(N)=Cc1ccccc1CCO</smiles>

$86 a, b$

Scheme 20: Synthesis of FPhe derivatives $\mathbf{8 8 a}, \mathbf{b}$ from aspartic acid derivatives.<smiles>NC(Cc1ccccc1CCF)C(=O)O</smiles>

93

\section{TFA/DCM 1:1, rt}<smiles>CC(C)(C)OC(=O)C(N)Cc1ccccc1CCF</smiles>

92

$0{ }^{\circ} \mathrm{C}-\mathrm{rt}$<smiles>CC(C)(C)OC(=O)C(Cc1ccccc1Br)NC(=O)OCc1ccccc1</smiles>

89 $\frac{\text { vinyl-Sn }(n-\mathrm{Bu})_{3}}{\mathrm{LiCl}, \mathrm{Pd}\left(\mathrm{Ph}_{3} \mathrm{P}\right)_{2} \mathrm{Cl}_{2}}$ DMF, $70^{\circ} \mathrm{C}, 16 \mathrm{~h}$<smiles>C=Cc1ccccc1CC(N)C(=O)OC(C)(C)C</smiles>

90
(1) $\mathrm{BH}_{3} \cdot \mathrm{THF}, \mathrm{THF}, 0^{\circ} \mathrm{C}-\mathrm{rt}$ (2) $\mathrm{NaBO}_{3} \cdot \mathrm{H}_{2} \mathrm{O}$, water, rt<smiles>CC(C)(C)OC(=O)C(N)Cc1ccccc1CCO</smiles>

91

TsCl, DMAP $\mathrm{Et}_{3} \mathrm{~N}, \mathrm{DCM}, \mathrm{rt}$<smiles>N[C@@H](Cc1ccccc1CC[18F])C(=O)O</smiles>

95
(1) $\left[{ }^{18} \mathrm{~F}\right] \mathrm{F}^{-} / \mathrm{Kryptofix}^{\circledR} 222 / \mathrm{K}^{+}$ complex, MeCN, $100^{\circ} \mathrm{C}, 15 \mathrm{~min}$

(2) $2 \mathrm{M}$ aq. $\mathrm{HCl}, 15 \mathrm{~min}$

(3) $4 \mathrm{M}$ aq. $\mathrm{NaOH}$

(4) HPLC<smiles>CC(C)(C)OC(=O)C(Cc1ccccc1CCO[As])NC(=O)c1ccccc1</smiles>

94 
idinophanes) 96 and the sodium salt of $o, m$, or $p$-fluoro or (trifluoromethyl)phenylpyruvic acids $\mathbf{9 7 a}-\mathbf{f}$. The reaction was carried out in presence of 0.5 equiv of zinc(II) acetate in the presence of $\mathrm{NaOMe}$. The initially formed complexes 98a-f underwent isomerization to 99a-f. Acid hydrolysis then gave the FPhe derivatives 53a,b, 53i, 81, and 101c, $\mathbf{d}$ with modest enantiomeric excesses (33-66\% ee) and in moderate yields [59] (Scheme 22).

A convenient preparative method for the synthesis of enantiomerically pure $o-, m-$, and $p$ - or pentafluorinated phenylalanines 53a, 81, 101c, and 107 was carried out by the alkylation of glycine. The Ni(II) complex $\mathbf{1 0 4}$ was obtained through the reaction of 102 with glycine $(\mathbf{1 0 3})$ and $\mathrm{Ni}\left(\mathrm{NO}_{3}\right)_{2}$. The subsequent alkylation of complex 104 with fluorine-containing benzyl chlorides 105a-d followed by hydrolysis with $\mathrm{HCl}$ afforded enantiomerically enriched $(<90 \%$ ee) $(S)$-fluorinated phenylalanine derivatives 53a, 81, 101c, and 107 [60,61] (Scheme 23).

Following the previous method, the chiral auxiliary $\mathbf{1 0 8}$ was readily cleaved under mild acidic conditions to afford the hydrochloride salt of 3,4,5-trifluoro-Phe $\mathbf{1 0 9}$ in $86 \%$ yield and $95 \%$ ee, indicating very low racemization [62] (Scheme 24).

\subsection{PAM enzymatic catalytic amination of $(E)$-cinnamic acid}

The enzyme phenylalanine aminomutase (PAM) from Taxus chinensis catalyzes the stereoselective isomerization of $\alpha$-phenylalanine to $\beta$-phenyalanine 111a-c. Mechanistic studies showed that $(E)$-cinnamic acid is an intermediate in this transformation [63]. Accordingly, addition of ammonia to $o, m$, or $p$-fluoro- $(E)$-cinnamic acids 110a-c catalyzed by PAM afforded $(R)$-fluoro- $\beta$-phenylalanines 111a-c and $o, m$, and $p$ - $(S)$-fluorophenylalanines 53a, 81, 101c, respectively, with excellent enantioselectivities $(<99 \%$ ee) (Scheme 25$)$.

\subsection{From enamine intermediates}

The synthesis $(R)$-2,5-difluorophenylalanine derivative $\mathbf{1 1 5}$ was carried out by coupling the commercially available aldehyde $\mathbf{5 5}$ and $N$-Boc phosphonate glycinate $\mathbf{1 1 2}$ to generate the enamino ester intermediate 113. The asymmetric hydrogenation of this enamine afforded the $N$-Boc-protected $(R)$-2,5-difluorophenylalanine ester 114 with $>99 \%$ ee. A following alkaline hydrolysis of the ester 114 gave $N$-Boc- $(R)$-2,5-difluorophenylalanine 115 (Scheme 26) [50].

After compiling the above synthetic methods, a number of conclusions can be drawn regarding the synthesis of FPhe ana-<smiles>[R][R]1ccc(C)cc1</smiles>

a, 53a<smiles>Cc1ccccc1C(F)(F)F</smiles>

b, 53b<smiles>Cc1cccc(C(F)(F)F)c1</smiles>

d, 101d c, 101c<smiles>Cc1ccc(F)c(C(C)(F)F)c1</smiles>

\section{5 equiv $\mathrm{Zn}$ (acetate) $)_{2}$ $\mathrm{H}_{2} \mathrm{O}, \mathrm{MeOH} / \mathrm{NaOMe}$}

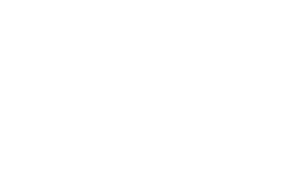

f, 81

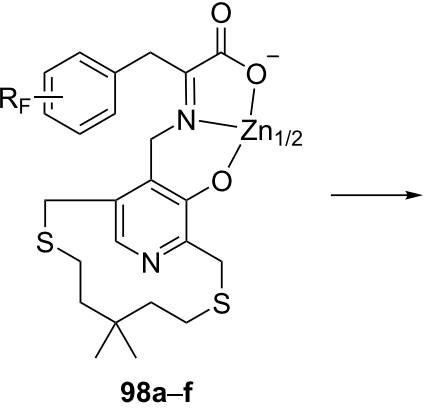

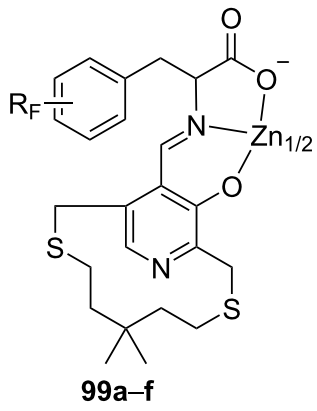

$1 \mathrm{M} \mathrm{HCl}$<smiles>N[C@@H](Cc1ccc(F)cc1)C(=O)O</smiles><smiles>CC1(C)CCSCC2=CN=C(CSCC1)C(O)=C(C=O)C(C)(C)CCSC2</smiles>

$53 a, b\left(R_{F}=a, b\right)$

$53 i\left(R_{F}=e\right)$

$81\left(R_{F}=f\right)$

100 
<smiles>CO[N+](=O)[O-]</smiles>

102<smiles>O=C1Nc2ccccc2C2=C(c3ccccc3)N3CC(=O)N(Cc4ccccc4)N3CCCC12</smiles>

104

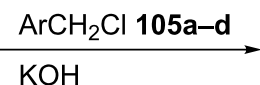<smiles>N#CCC1C(=O)O[N+]2(Cc3ccccc3)N=C1c1ccccc1NC(=O)C1CCCN12</smiles>

106a-d $2 \mathrm{M} \mathrm{HCl}, 50^{\circ} \mathrm{C}$<smiles>NC(C[Te])C(=O)O</smiles>

53a $(\mathrm{Ar}=\mathbf{a})$

$81(A r=b)$

101c $(A r=c)$

$107(\mathrm{Ar}=\mathrm{d})$

Scheme 23: Synthesis of FPhe derivatives via $\mathrm{Ni}^{2+}$ complexes.<smiles>O=C1CCCN2C(Cc3cc(F)c(F)c(F)c3)C(=O)N(c3ccccc3)[B-]2(Nc2ccccc2-c2ccccc2)O1</smiles>

108<smiles>CO[C@H](C)[C@H](C)O</smiles>

$109,86 \%$ $95 \%$ ee
Scheme 24: Synthesis of 3,4,5-trifluorophenylalanine hydrochloride (109).

logues of type I and II. The most convenient method involved a Negishi cross coupling of an aryl halide and the $\mathrm{Zn}$ homoenolate of the protected $(R)$-iodoalanine 2 using a $\operatorname{Pd}(0)$ catalyst. This method provided a versatile range of fluorinated phenylalanine products with high enantioselectivities and in acceptable yields.

\section{Synthesis of $\beta$-fluorophenylalanines of type III}

2.1. Fluorination of protected $(1 R, 2 R)$-2-amino-Lphenylpropane-1,3-diol

Recently, Okuda et al. reported the synthesis of (3R)-3-fluoro-Lphenylalanine (121) from $(1 R, 2 R)$-2-amino-L-phenylpropane1,3-diol (116). Thus, Boc-protection of the amine group in 116 followed by the protection of the primary hydroxy group (Alloc) gave alcohol 117 in good yield. The fluorination of 117 was achieved by treatment with DAST to form 118. Then, selective removal of the Alloc protecting group using $\mathrm{Pd}\left(\mathrm{PPh}_{3}\right)_{4}$, was followed by oxidation of the resulting Boc-protected amino alcohol 119 to give the $N$-Boc-protected acid 120 in good yield. Finally, removal of the Boc group then generated the free amino acid (3R)-3-fluoro-L-phenylalanine (121) [64] (Scheme 27). Okuda's group used 121 in the synthesis of a nucleoside that could be used to assess the transition state of a ribosome-catalyzed peptide-bond formation [64].<smiles>O=C(O)C=Cc1cc[Y]cc1</smiles>

PAM, $6 \mathrm{M} \mathrm{NH}_{3}, \mathrm{CO}_{2}$, buffer<smiles>[Y]c1ccc([C@@H]([NH3+])CC(=O)[O-])cc1</smiles>

$111 a-c$<smiles>[Y][C](Cc1ccncc1)C(=O)[O-]</smiles>

53a $(X=a)$

$81(X=b)$ $101 c(X=c)$

a: $X=0-F$

b: $\mathrm{X}=m-\mathrm{F}$

c: $\mathrm{X}=p-\mathrm{F}$ 


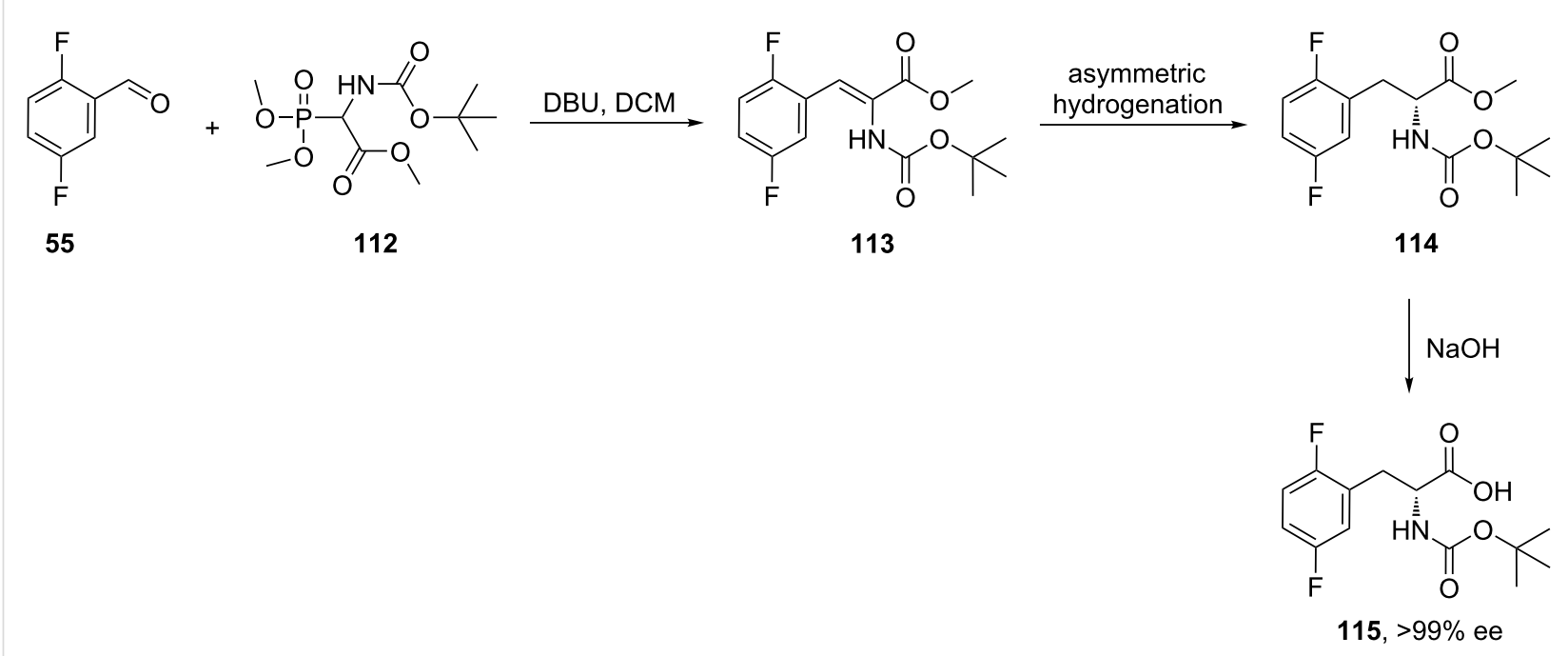<smiles>COC(=O)OC(=O)OC(=O)OC(=O)O</smiles>

116

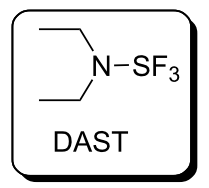<smiles>NC(COC(=O)O)C(O)c1ccccc1</smiles>

117<smiles>O=C(NC(C(=O)O)C(F)c1ccccc1)c1ccccc1</smiles>

120<smiles>CC(C)(C)OCC(NC(=O)OC(C)(C)C)C(F)c1ccccc1</smiles>

$118,58 \%$

$\mathrm{Pd}\left(\mathrm{Ph}_{3} \mathrm{P}\right)_{4}$ morpholine $\frac{\text { aq. } \mathrm{NaClO}, \mathrm{TEMPO}}{n-\mathrm{Bu}_{4} \mathrm{NBr}, \mathrm{NaHCO}_{3}}$<smiles>O=C(N[C@@H](CO)C(F)c1ccccc1)c1ccccc1</smiles>

Scheme 27: Synthesis of $\beta$-fluorophenylalanine via 2-amino-1,3-diol derivatives.

\subsection{Stereoselective benzylic fluorination of $\mathrm{N}$-(2- phenylacetyl)oxazolidin-2-one using NFSI}

Treatment of oxazolidinone $\mathbf{1 2 2}$ with $\mathrm{N}$-fluorobenzenesulfonimide (NFSI) in the presence of NaHMDS afforded the fluorinated oxazolidinone derivative $\mathbf{1 2 3}$. The reductive removal of the chiral auxiliary with $\mathrm{LiBH}_{4}$ resulted in alcohol $\mathbf{1 2 4}$ which was oxidized by Dess-Martin periodinane to give $(S)-(-)-2-$ fluoro-2-phenylacetaldehyde (125). This aldehyde is prone to racemization and decomposition and therefore was directly converted to the arylidene derivative $\mathbf{1 2 7}$, by treatment with $p$-toluenesulfinamide (126). Then, reaction of $127(1.0 \mathrm{mmol})$ with $1.5 / 1.0$ equiv of diethylaluminum cyanide $\left(\mathrm{Et}_{2} \mathrm{AlCN}\right) /$ iPrOH at $-78{ }^{\circ} \mathrm{C}$ in THF gave nitrile 128. Deprotection of the latter, followed by hydrolysis of the nitrile group afforded syn(2S,3S)-(+)-3-fluorophenylalanine (129) [65] (Scheme 28) .

\subsection{Multistep synthesis from ethyl trifluoropyruvate hemiketal}

The reaction of ethyl trifluoropyruvate hemiketal 130 with thionyl chloride in pyridine afforded the chlorinated derivative 131, which upon treatment with zinc powder in DMF, afforded the dihalogenated olefin 132. The substitution of one fluorine atom in $\mathbf{1 3 2}$ with a tributylstannyl group to give $\mathbf{1 3 3}$ was accomplished by the reaction with $\left(\mathrm{Bu}_{3} \mathrm{Sn}\right)_{2} \mathrm{CuLi}$ in THF at $-78^{\circ} \mathrm{C}$. The reaction took place following an addition-elimination mechanism. Then, coupling of $\mathbf{1 3 3}$ with iodobenzene in the presence of $\mathrm{Pd}\left(\mathrm{PPh}_{3}\right)_{4}$ and $\mathrm{CuI}$ as the co-catalyst afforded ethyl (E)-3-phenyl-3-fluoro-2-methoxypropenoate (134) which was converted into the corresponding $\alpha$-ketoacid 135 by treatment with trimethylsilyl iodide. Finally, the reaction of $\mathbf{1 3 5}$ with aqueous ammonia followed by reduction with sodium borohy- 
<smiles>CC1C(c2ccccc2)OC(=O)N1C(=O)Cc1ccccc1</smiles>

122<smiles>CC1C(c2ccccc2)OC(=O)N1C(=O)C(F)c1ccccc1</smiles>

123<smiles>O=C(C(F)C(=O)[C@H](F)c1ccccc1)[C@H](F)c1ccccc1</smiles>

124

$$
\begin{gathered}
\mathrm{F}-\mathrm{NO} \\
\mathrm{SO}_{2} \mathrm{Ph} \\
\mathrm{SO}_{2} \mathrm{Ph} \\
\mathrm{NFSI}
\end{gathered}
$$

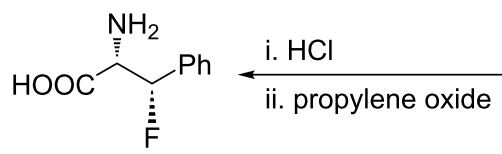

129

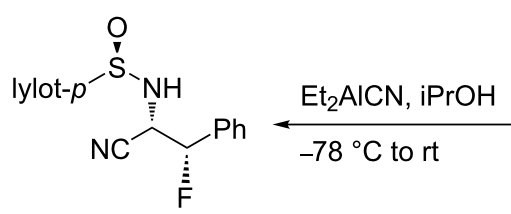

128<smiles>O=[As](O)/N=C/C(F)c1ccccc1</smiles>

127

Scheme 28: Synthesis of $\beta$-fluorophenylalanine derivatives via the oxazolidinone chiral auxiliary 122.

dride gave the racemic erythro- $\beta$-fluorophenylalanine $\mathbf{1 3 6}$ in $40 \%$ yield [66] (Scheme 29).

\subsection{Fluorodehydroxylation of}

\section{$\beta$-hydroxyphenylalanine}

Alternatively, Kollonitach et al. prepared racemic 3-fluorophenylalanine (136) through the fluorodehydroxylation of 3-hydroxyphenylalanine (137) using sulfur tetrafluoride $\left(\mathrm{SF}_{4}\right)$ in HF [67] (Scheme 30).

\subsection{Ring opening of aziridine derivatives by HF/Py} The ring opening reaction of aziridines $\mathbf{1 3 8 a}, \mathbf{b}$ by treatment with hydrogen fluoride in pyridine afforded 3-fluorophenylalanine esters 139a,b. The subsequent enzymatic hydrolysis of

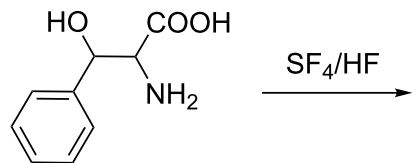

137

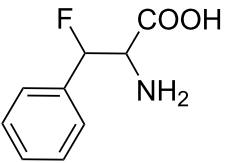

136
Scheme 30: Synthesis of $\beta$-fluorophenylalanine (136) via fluorination of $\beta$-hydroxyphenylalanine (137).

esters 139a,b gave the threo-isomer $\mathbf{1 3 6}$ in an enantiomerically pure form [68,69] (Scheme 31).

On the other hand, Wade et al. reported that ester $138 \mathrm{~b}(\mathrm{R}=$ iPr) afforded the isopropyl 3-fluorophenylalaninate (139b) as

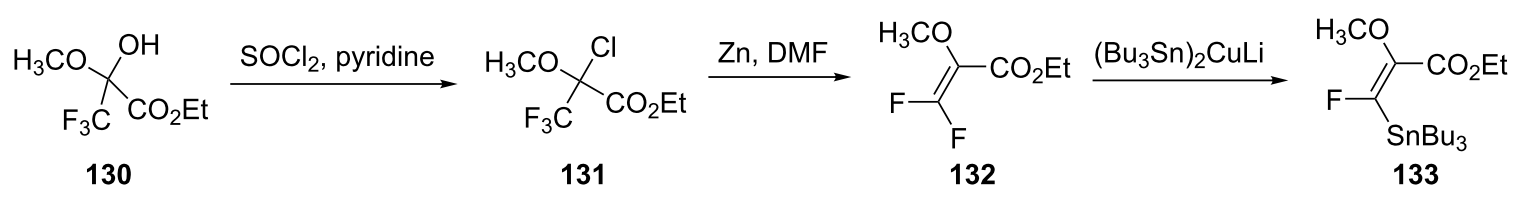<smiles>NC(C(=O)O)C(F)c1ccccc1</smiles>

$136,40 \%$ aq. $\mathrm{NH}_{3}, \mathrm{NaBH}_{4}$<smiles>O=C(O)C(F)c1ccccc1</smiles><smiles>C[SiH3]C([SiH3])[SiH3]</smiles>

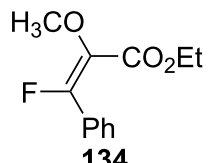


<smiles>O=C(O)C1NC1c1ccccc1</smiles>

$138 \mathrm{a}, \mathrm{b}$
HF, pyridine

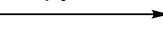<smiles>[R]OC(=O)C(N)C(F)c1ccccc1</smiles>

$139 a, b$ enzymatic hydrolysis<smiles>N[C@@H](C(=O)O)C(F)c1ccccc1</smiles>

threo-136

a $R=E t$

b $\mathrm{R}=\mathrm{iPr}$

Scheme 31: Synthesis of $\beta$-fluorophenylalanine from aziridine derivatives.

racemate in $45-50 \%$ yield [70] under similar reaction conditions (Scheme 31).

\subsection{Fluorination and reductive amination of phenylpyruvate}

A direct fluorination of the ester derivatives of phenylpyruvic acids $140 \mathbf{a}, \mathbf{b}$ with $\mathrm{F}_{2}$ followed by hydrolysis of the resulting fluoropyruvates in $50 \%$ isopropanol in the presence of $\mathrm{NaHCO}_{3}$ gave 3-fluoro-3-phenylpyruvate $\mathbf{1 4 1}$ in $40-50 \%$ yields [68]. The direct reductive amination gave a partially racemized mixture of threo and erythro-136 with the erythro stereoisomer $\mathbf{1 3 6}$ as the major product (Scheme 32).
The reductive amination of 3-fluoro-3-phenylpyruvic acid (144) obtained by the fluorodehydroxylation of the enol form of ethyl 3-phenylpyruvate 142, using DAST instead of $\mathrm{SF}_{4}$ followed by hydrolysis, produced both threo and erythro-diastereomers of 136 [68] (Scheme 33).

\subsection{Photocatalyzed benzylic fluorination of} $N$-phthalimido phenylalanine

The photocatalyzed benzylic fluorination of phthalimide-protected phenylalanine methyl ester $\mathbf{1 4 5}$, using the photosensitizer 1,2,4,5-tetracyanobenzene (TCB), and Selectfluor in acetonitrile was carried out using a pen lamp $\left(\lambda_{\max }=302 \mathrm{~nm}\right)$. By<smiles>[R]OC(=O)C(=O)Cc1ccccc1</smiles>

$140 \mathrm{a}, \mathrm{b}$

\section{(1) $F_{2}, N_{2}$ \\ (2) $\mathrm{NaHCO}_{3}, \mathrm{iPrOH}$}

$\mathrm{R}=\mathrm{Me}$

b $R=E t$<smiles>O=C(O[Na])C(=O)C(F)c1ccccc1</smiles>

141<smiles>N[C@@H](C(=O)O)[C@@H](F)c1ccccc1</smiles>

erythro-136

Scheme 32: Synthesis of $\beta$-fluorophenylalanine 136 via direct fluorination of pyruvate esters.

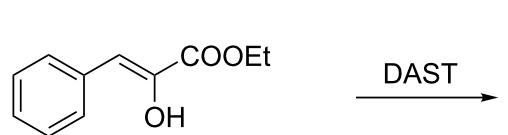

enol 142<smiles>CCOC(=O)C(F)c1ccccc1</smiles>

143

\section{hydrolysis}<smiles>O=C(O)C(=O)C(F)c1ccccc1</smiles>

144 reductive amination<smiles>N[C@@H](C(=O)O)[C@@H](F)c1ccccc1[C@@H](F)[C@@H](N)[C@H](N)C(=O)O</smiles>

erythro-136

threo-136 
this route, the $\beta$-fluoro derivative $\mathbf{1 4 6}$ was obtained in $62 \%$ yield as racemic mixture [71] (Scheme 34). Recently, Egami and coworker also synthesized compound $\mathbf{1 4 6}$ in $43 \%$ yield $(\mathrm{dr}=1: 1)$ via the fluorination of $\mathbf{1 4 5}$, however without TCB as photosensitizer, but instead using an LED light source $(365 \mathrm{~nm})$ and Selectfluor in MeCN [72].

Alternatively, a visible light (14 Watt CFL) mediated benzylic fluorination of a series of $N$ - and $C$-terminally protected phenylalanines 147 using Selectfluor and dibenzosuberenone in acetonitrile, afforded the $\beta$-fluorophenylalanine derivatives 148 in variable yields with partial racemization. Phthalimido and trifluoroacetyl $N$-terminal protecting groups $\left(\mathrm{R}^{1}=\mathrm{Phth}\right.$ or TFA) and unprotected $C$-terminal derivatives $\left(\mathrm{R}^{2}=\mathrm{H}\right)$ provided the most efficient outcomes (80 and $67 \%$ yield, respectively). An $\mathrm{N}$-acetyl group was also suitable as protecting group for the reaction providing the desired product with $57 \%$ yield. Also, methyl and ethyl esters as $C$-terminal protecting groups in combination with phthalimino as the $\mathrm{N}$-terminal protecting group were both successfully explored. However, when the trifluoroacetyl amide was used as a substrate the methyl ester performed better than the ethyl ester ( $74 \%$ versus $60 \%$ yield). However, $N$-protecting groups such as Boc, Fmoc, and Cbz were not compatible with the fluorination ( $0-10 \%$ yield). Moreover, when tert-butyl, trityl, and adamantyl protecting groups were installed for $C$-terminal protection additional fluorination, decomposition, and consequently low yields of the $\beta$-fluorinated derivatives 148 were observed [73] (Scheme 35).

\subsection{Fluorination of aziridinium derivatives}

The $N, N$-dibenzylated 3-fluorophenylalanine derivative $\mathbf{1 5 1}$ was prepared with excellent diastereoisomeric ratio $(\mathrm{dr}>99: 1)$ from $\alpha$-hydroxy- $\beta$-amino ester 142. In this case, XtalFluor-E was used to activate the $\mathrm{OH}$ group in the substrate and displaced by neighboring amino-group participation creating an aziridinium intermediate 150. The latter then was opened stereo- and regioselectively by fluoride to give $\mathbf{1 5 1}$ in good yield and high diastereoisomeric purity (Scheme 36). The subsequent deprotection of 151 had to be achieved with $\mathrm{BrO}_{3}{ }^{-}$, because hydrogenolysis resulted in defluorination [74].

Alternatively, a series of substituted anti- $\beta$-fluorophenylalanine derivatives $\mathbf{1 5 4 a}-\mathbf{d}$ was obtained from the corresponding enantiopure $\alpha$-hydroxy- $\beta$-aminophenylalanine esters $[75,76]$ 152a-d using XtalFluor-E. The reaction also included an aziridinium ion rearrangement as the key step. Deprotection of the resultant $\beta$-fluoro- $\alpha$-amino acid esters 153a-d afforded the corresponding enantiopure anti- $\beta$-fluorophenylalanines $\mathbf{1 5 4 a - d}$ in good yield and high diastereoisomeric purities [74] (Scheme 37).

The deoxyfluorination of the enantiopure $\alpha$-hydroxy- $\beta$-amino ester 152a or $\alpha$-amino- $\beta$-hydroxyphenylalanine ester 155 [74-<smiles>COC(=O)C(Cc1ccccc1)Nc1ccccc1</smiles>

145
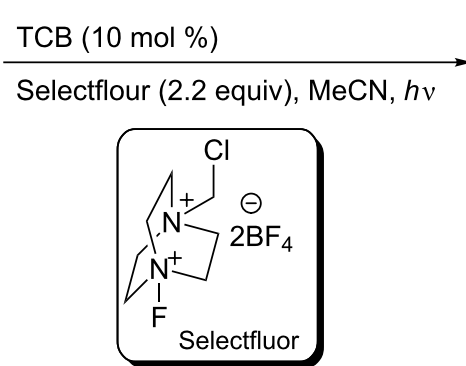<smiles>COC(=O)C(c1ccccc1)C(F)c1ccccc1</smiles>

$146,62 \%$

Scheme 34: Synthesis of $\beta$-fluorophenylalanine derivatives using photosensitizer TCB.<smiles>[R]CNC(Cc1ccccc1)C(=O)O[R]</smiles>

147 dibenzosuberenone (5 mol \%)

Selectfluor (2.0 equiv), MeCN, visible light, $16 \mathrm{~h}$

$\mathrm{R}^{1}=\mathrm{Boc}, \mathrm{Fmoc}, \mathrm{Cbz}, \mathrm{Ac}$, phth, TFA

$\mathrm{R}^{2}=\mathrm{H}, \mathrm{Me}, \mathrm{Et}, t-\mathrm{Bu}, \mathrm{Tr}$, Ada 
<smiles>CCOC(=O)C(O)C([NH3+])c1ccccc1</smiles>

149

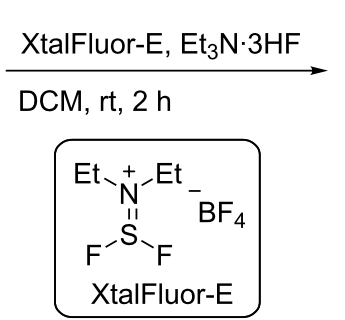<smiles>[CH-]C</smiles><smiles>CCOC(=O)C([NH2+]c1ccccc1)C(F)c1ccccc1</smiles>

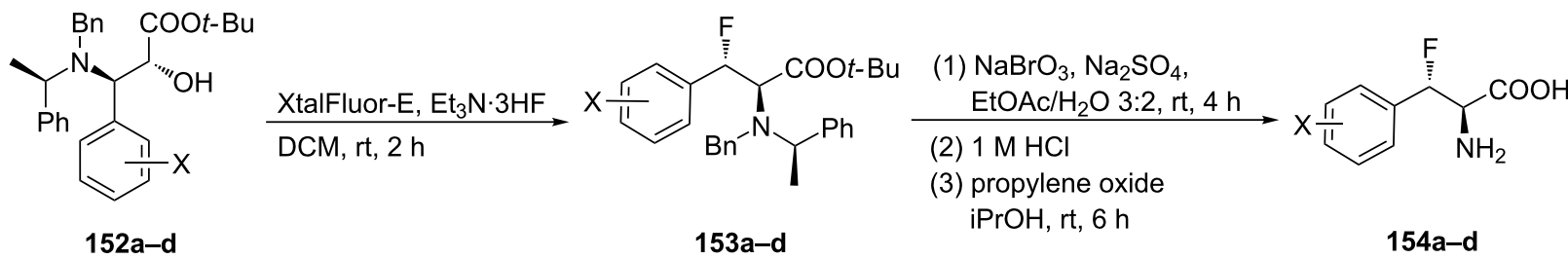
a: $\mathrm{X}=\mathrm{H}$
b: $\mathrm{X}=4-\mathrm{CF}_{3}$
c: $X=3-F$
d: $X=4-F$

Scheme 37: Synthesis of $\beta$-fluorophenylalanine derivatives via fluorination of $\alpha$-hydroxy- $\beta$-aminophenylalanine derivatives 152.

76] under the same conditions proceeded via aziridinium ion 156 and generated $\beta$-fluoro- $\alpha$-amino ester 153a in good yield and high diastereoisomeric purity $(\mathrm{dr}>99: 1)$ (Scheme 38).

\subsection{Direct fluorination of $\beta$-methylene $\mathrm{C}\left(\mathrm{sp}^{3}\right)-\mathrm{H}$} The direct fluorination of $\beta$-methylene $\mathrm{C}\left(\mathrm{sp}^{3}\right)-\mathrm{H}$ bonds of Phe derivatives $\mathbf{1 5 7 a - v}$ having installed the bidentate auxiliary, 2-(pyridine-2-yl)isopropylamine (PIP-amine) 158, was attempted using Selectfluor in the presence of $\mathrm{Pd}(\mathrm{OAc})_{2}$ as a catalyst. The corresponding $\beta$-fluoro derivatives $159 \mathbf{a}-\mathbf{v}$ were obtained with high stereoselectivity using DCM and $\operatorname{PrCN}$ as co-solvent $(30: 1 \mathrm{v} / \mathrm{v})$. Interestingly reducing the $\mathrm{Pd}(\mathrm{OAc})_{2}$ concentration from $10 \mathrm{~mol} \%$ to $6 \mathrm{~mol} \%$ led to an improved yield of $73 \%$ for $159 \mathrm{a}, 159 \mathrm{~g}$, and 159t. Selectfluor was found superi-

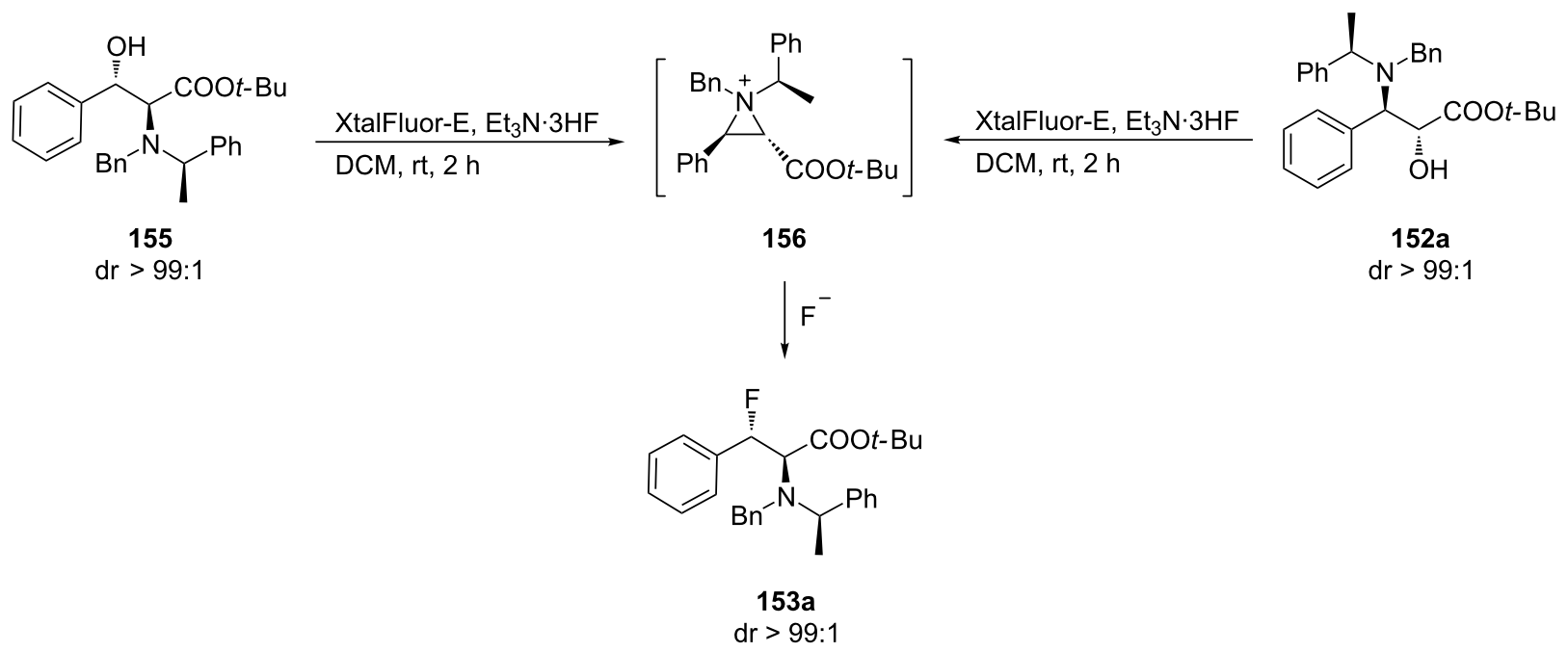


or to other fluorination reagents such as fluoropyridinium tetrafluoroborate, 2,4,6-trimethylfluoropyridinium tetrafluoroborate, or NFSI. The fluorination process was explored with a broad range of substituted Phe derivatives. The removal of the PIP auxiliary group without affecting the newly introduced fluorine atom was attempted by a two-step, one-pot protocol involving an in situ esterification of a highly electrophilic pyridinium triflate intermediate [77] and afforded the anti- $\beta$-fluoro- $\alpha$-amino acid methyl ester 160a in 52\% yield and with $98.8 \%$ ee (Scheme 39).

On the other hand, when the quinoline-based ligand $\mathbf{1 6 2}$ was used, it was shown to promote the palladium-catalyzed direct electrophilic fluorination of $\beta$-methylene $\mathrm{C}\left(\mathrm{sp}^{3}\right)-\mathrm{H}$ bonds Thus, fluorinations of L-phenylalanine 4-trifluoromethylphenylamides 161a-l carrying a range of functional groups such as fluoro, chloro, bromo, methoxy, acetyl, cyano, nitro, and trifluoromethyl, were well-tolerated and afforded the corresponding anti- $\beta$-fluoro- $\alpha$-amino acids 163a-l in moderate to excellent yields [78] (Scheme 40).

\section{Synthesis of $\beta, \beta$-difluorophenylalanine derivatives of type IV via 2-phenyl-2,2- difluoroacetaldehyde derivatives}

2-Phenyl- and 2-(4-fluorophenyl)-2,2-difluoroacetaldehyde 164a and 164b proved to be key starting points for the synthesis of $\beta, \beta$-difluorophenylalanine analogs $168 \mathbf{a}, \mathbf{b}$. The conversion of $164 \mathbf{a}, \mathbf{b}$ into their respective cyanohydrins $165 \mathbf{a}, \mathbf{b}$ followed by acid hydrolysis with gaseous $\mathrm{HCl}$ in ethanol afforded the $\alpha$-hydroxy esters 166a,b. Dess-Martin oxidation $[79,80]$ of the latter, followed by hydrolysis of the ester gave keto acids 167a,b. Finally, the reductive amination of $\mathbf{1 6 7 a}, \mathbf{b}$ with $25 \%$ aqueous ammonia and $\mathrm{NaBH}_{4}$ afforded the racemic $\beta, \beta$-difluorophenylalanine derivatives 168a,b in $67 \%$ yield [81] (Scheme 41).

An alternative approach to the difluorinated compound 168a was achieved by the condensation of 164a with $(S)$-1-phenylethylamine (169), to give the imine 170. Heating of imine $\mathbf{1 7 0}$ with TMSCN in the presence of zinc iodide [82] generated the nitrile $\mathbf{1 7 1}$ as a 1:1 mixture of diastereoisomers which was

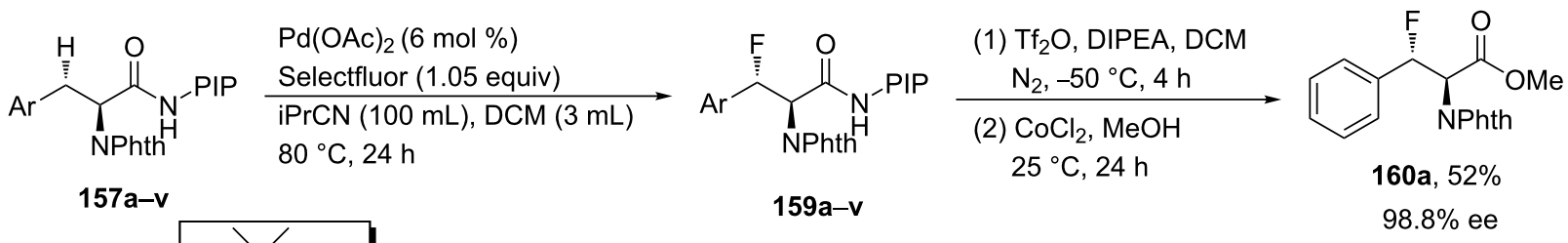<smiles>NC1(c2ccccn2)CC2CCCCC1C2</smiles>

$\operatorname{Ar}=$<smiles>Ic1ccccc1</smiles>

a<smiles>Cc1ccc(C)cc1</smiles>

h<smiles>Cc1ccc(C(F)(F)F)cc1</smiles>

$\mathbf{0}$<smiles>Cc1ccc(F)c(F)c1</smiles>

b<smiles>Cc1ccc(C#N)cc1</smiles>
i<smiles>Cc1ccc([N+](=O)[O-])c(F)c1</smiles>

c<smiles>Cc1ccc(Cl)cc1</smiles>

j<smiles>CC(C)(C)c1ccc(I)cc1</smiles>

p<smiles>COc1ccc(I)cc1</smiles>

q<smiles>Fc1ccc(I)cc1Cl</smiles>

d<smiles>Cc1ccc(C#N)cc1</smiles>

k<smiles>COc1cccc(C)c1</smiles>

$r$<smiles>Cc1ccc(I)cc1C</smiles>

e<smiles>Cc1ccc(B2OC(C)(C)C(C)(C)O2)cc1</smiles><smiles>Cc1cccc(C#N)c1</smiles>

I<smiles>Cc1cccc(F)c1</smiles>

s<smiles>O=[N+]([O-])c1ccc(I)cc1</smiles>

m<smiles>COc1ccc(I)cc1[N+](=O)[O-]</smiles>

$\mathbf{t}$<smiles>Brc1ccc(I)cc1</smiles>

g<smiles>Cc1ccc(F)cc1</smiles>

n<smiles>COC(=O)c1ccc(I)cc1</smiles>

v 
<smiles>O=C(Nc1ccc(C(F)(F)F)cc1)[C@H](CBr)NP</smiles>

161a-I
(1) $\mathrm{Pd}(\mathrm{OAc})_{2}(6 \mathrm{~mol} \%), 162$

Selectfluor (1.05 equiv), $\operatorname{iPrCN}(100 \mathrm{~mL}) / \mathrm{DCM}(3 \mathrm{~mL}), 80^{\circ} \mathrm{C}, 24 \mathrm{~h}$

(2) i. $\mathrm{Tf}_{2} \mathrm{O}$, DIPEA, DCM $\mathrm{N}_{2},-50^{\circ} \mathrm{C}, 4 \mathrm{~h}$ ii. $\mathrm{CoCl}_{2}, \mathrm{MeOH}, 25^{\circ} \mathrm{C}, 24 \mathrm{~h}$

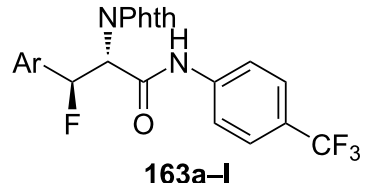

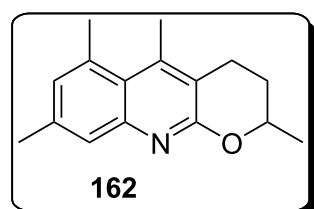

$\mathrm{Ar}=$<smiles>Cc1ccccc1</smiles>

a<smiles>COc1ccccc1C</smiles>

g<smiles>Cc1ccc(F)cc1</smiles>

b<smiles>Cc1ccc(C#N)cc1</smiles>

h<smiles>Clc1ccc(I)cc1</smiles>

C<smiles>Brc1ccc(Br)cc1</smiles>

d<smiles>N#Cc1ccc(I)cc1</smiles>

i<smiles>O=[N+]([O-])c1ccc(I)cc1</smiles>

$\mathbf{k}$<smiles>COc1ccc(I)cc1</smiles>

e<smiles>COc1cccc([Te])c1</smiles>

f

Scheme 40: Synthesis of series of $\beta$-fluorinated Phe derivatives using quinoline-based ligand 162 in the Pd-catalyzed direct fluorination of $\beta$-methylene $\mathrm{C}\left(\mathrm{sp}^{3}\right)-\mathrm{H}$ bonds.

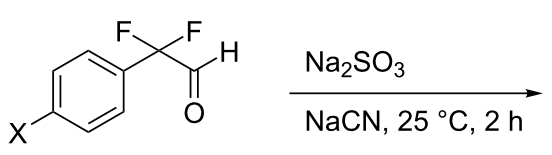

$164 a, b$<smiles>[X]c1ccc(C(F)(F)C(O)C#N)cc1</smiles>

$165 a, b$

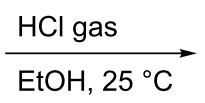

EtOH, $25^{\circ} \mathrm{C}$<smiles>[X]c1ccc(C(F)(F)C(N)C(=O)O)cc1</smiles>

168a,b $67 \%$ aq. $\mathrm{NH}_{3}(25 \%), 60^{\circ} \mathrm{C}, 5 \mathrm{~h}$

$\mathrm{NaBH}_{4}, 25^{\circ} \mathrm{C}, 30 \mathrm{~min}$
$166 a, b$

$\mathrm{NaHCO}_{3}(5 \%$ aq. iPrOH) $50{ }^{\circ} \mathrm{C}, 24 \mathrm{~h}$<smiles>[X]c1ccc(C(F)(F)C(O)C(=O)OCC)cc1</smiles><smiles>[X]c1ccc(C(F)(F)C(=O)C(=O)O)cc1</smiles>

$167 a, b$

\footnotetext{
a: $X=\mathrm{H}$

b: $X=F$
}

Scheme 41: Synthesis of $\beta, \beta$-difluorophenylalanine derivatives from 2,2-difluoroacetaldehyde derivatives 164a,b.

immediately hydrolyzed to provide the racemic carboxamide 172. The subsequent removal of the chiral auxiliary by catalytic hydrogenation then afforded the carboxamide 173. Finally, an acid-mediated hydrolysis of the carboxamide $\mathbf{1 7 3}$ to generate the free amino acids L- or D-168a, was carried out with aqueous $\mathrm{H}_{2} \mathrm{SO}_{4}$. However, the acid hydrolysis step was accompanied with extensive racemization $[81,83]$ (Scheme 42).

\section{Synthesis of $\alpha$-fluorophenylalanine of type} V via $\alpha$-fluorination of Phe derivatives

The successful $\alpha$-fluorination of phenylalanine derivative $\mathbf{1 7 4}$ carrying a picolinamide auxiliary to give $\mathbf{1 7 6}$ was carried out using Selectfluor as the fluorination reagent. The direct $\alpha-\mathrm{C}\left(\mathrm{sp}^{3}\right)-\mathrm{H}$ fluorination of the starting compound $\mathbf{1 7 4}$ was catalyzed by $\mathrm{Cu}(\mathrm{OAc})_{2}$ with $(R)$-3-hydroxyquinuclidine ligand 175. 


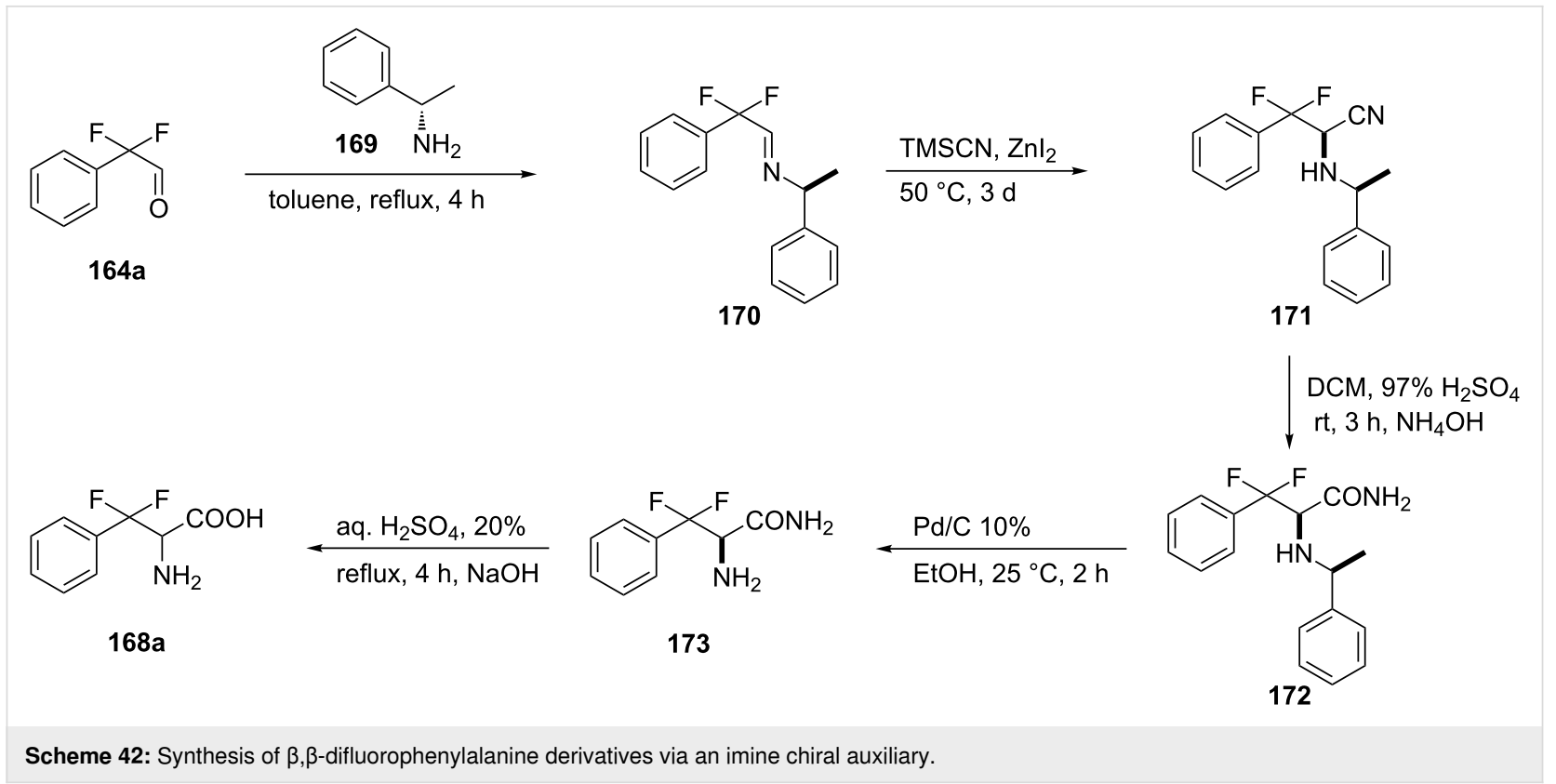

Comparative studies demonstrated that using ligand $\mathbf{1 7 5}$ rather than other ligands gave higher yields and no $\beta$-elimination products. The effective removal of the auxiliary using triflic anhydride with $\mathrm{LiOH}$ as nucleophile, gave product 177a in good yield. Alternative nucleophiles such as EtOH or methyl esters of amino acids, in the presence of catalytic amounts of $\mathrm{CoCl}_{2}$,

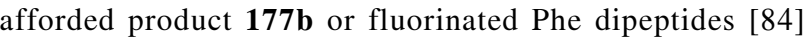
$\mathbf{1 7 7} \mathbf{c}-\mathbf{g}$ as racemic mixtures (Scheme 43 ).

\section{Pharmaceutical applications of fluorinated phenylalanine derivatives}

Peptides and proteins containing FPhe are important tools to identify enzyme-substrate complexes, mechanisms of protein aggregation, and modifying the chemical and thermal stabilities of proteins. The properties of protein were preserved, when low levels of fluorine are incorporated into the constituent amino acids, and were comparable with that of the original proteins.<smiles>O=C(Nc1ccccn1)C(Cc1ccccc1)[NH+]([O-])[O-]</smiles>

$\mathrm{Cu}(\mathrm{OAc})_{2}, 175$

Selectfluor, $\mathrm{Ag}_{2} \mathrm{CO}_{3}$ $\mathrm{MeCN}, 115^{\circ} \mathrm{C}, 8 \mathrm{~h}$

174

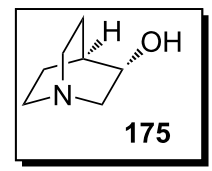<smiles>O=C(Nc1ccccn1)C(F)(Cc1ccccc1)c1ccccc1</smiles>

176

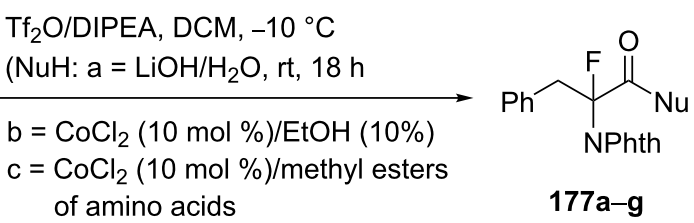

$\mathrm{Tf}_{2} \mathrm{O} / \mathrm{DIPEA}, \mathrm{DCM},-10^{\circ} \mathrm{C}$

(NuH: $\mathrm{a}=\mathrm{LiOH} / \mathrm{H}_{2} \mathrm{O}, \mathrm{rt}, 18 \mathrm{~h}$

$\mathrm{b}=\mathrm{CoCl}_{2}(10 \mathrm{~mol} \%) / \mathrm{EtOH}(10 \%)$

of amino acids

$177 \mathrm{a}-\mathrm{g}$<smiles>O=C(O)C(F)(Cc1ccccc1)[PH2+]c1ccccc1</smiles>

a<smiles>CCOC(=O)C(F)([PH2+])Cc1ccccc1</smiles>

b<smiles>CC(=O)CNC(=O)C(F)(Cc1ccccc1)[PH+]c1ccccc1</smiles>

c<smiles>CC(=O)C(C)NC(=O)[C@](F)(Cc1ccccc1)[PH+]c1ccccc1</smiles>

d<smiles>CC(=O)[C@H](C)NC(=O)C(F)(Cc1ccccc1)[PH+]c1ccccc1</smiles>

e<smiles>COC(=O)[C@@H]1CCCN1C(=O)C(F)([PH2+])Cc1ccccc1</smiles>

f<smiles>COC(=O)C1CCCN1C(=O)C(F)([PH+])Cc1ccccc1</smiles>

g 
Helpfully, fluorine incorporation may favorably adjust protein function including improved stability and substrate selectivity.

\subsection{Applications of FPhe derivatives in positron emission tomography (PET)}

The molecular imaging technique positron emission tomography (PET) provides information on tumor metabolism, which allows for a more accurate diagnostic and therapy response in neuro-oncology, compared to, for example, magnetic resonance imaging (MRI). PET is particularly well-suited to differentiate neoplastic tissue from non-specific changes induced by chemotherapy treatments [85]. PET is particularly used for the early detection of tumors and metastases, and is an established tool for the diagnosis, staging, and the treatment planning of various malignancies. The selective imaging of tumors using PET exploits radiotracers that target aberrant cellular metabolism or increased protein expression $[86,87]$. Here, the ${ }^{18} \mathrm{~F}$ isotope is particularly useful for the preparation of radiotracers to be used in PET due to its relatively long half-life (109 $\mathrm{min})$. In this section we highlight two selected ${ }^{18} \mathrm{FPhe}$ derivatives which are used for PET tumor detection. 4-Borono-2-[ $\left.{ }^{18} \mathrm{~F}\right]$ fluoro-D,Lphenylalanine $\left(\left[{ }^{18} \mathrm{~F}\right] \mathrm{FBPA}, \mathbf{7 0}\right)$, is a fluorinated derivative of the parent compound designed for boron neutron capture therapy (BNCT) [53,88-92]. This compound was used for PET imaging of melanoma in animal models.

The low affinity of $\mathbf{1 7 8}$ for the L-type amino acid transporter 1 (LAT1), however, limited the use of this compound as PET radiotracer for brain tumor imaging [93-96]. Therefore, for further analysis and comparison with $\mathbf{1 7 8}$ (performed in vitro), as the most promising candidate $2-\left[{ }^{18} \mathrm{~F}\right]-2$-fluoroethyl-L-phenylalanine (2- $\left[{ }^{18}\right.$ F]FELP, 95) was selected. In a F98 glioblastoma rat model, $2-\left[{ }^{18} \mathrm{~F}\right]$ FELP exhibited improved in vitro characteristics over $\left[{ }^{18} \mathrm{~F}\right]$ FET 178, especially in view of the affinity and specificity for system L [58]. Accordingly, 2-[ ${ }^{18}$ F]FELP 95 emerged as a promising PET radiotracer for brain tumor imaging [97-101] (Figure 2).

\subsection{Incorporation of FPhe for the synthesis of fluorinated drugs}

5.2.1. Melflufen, an anticancer drug: 4-Fluoro-L-phenylalanine ester is required for the synthesis of melflufen (179), an anticancer drug currently being in clinical trials for the treatment of relapsed and refractory multiple myeloma (RRMM) $[102,103]$. Melflufen is a next generation form of the more historical drug, melphalan 180 (Figure 3).<smiles>CCOC(=O)[C@H](Cc1ccc(F)cc1)NC(=O)[C@H](N)Cc1ccc(N(CCCl)CCCl)cc1</smiles><smiles>N[C@@H](Cc1ccc(N(CCCl)CCCl)cc1)C(=O)O</smiles>

Figure 3: Structures of melfufen (179) and melphalan (180) anticancer drugs.

5.2.2. Gastrazole (JB95008), a CCK2 receptor antagonist: 2-Fluoro-L-phenylalanine derivatives are required for the synthesis of gastrazole (JB95008, 181), a potent and highly selective cholecystokinin-2 (CCK2) receptor antagonist, originally developed at the James Black Foundation [104-109]. Roberts et al. demonstrated its inhibitory activity of gastrin-stimulated growth of pancreatic cancer both in vitro and in vivo studies [110] (Figure 4).

5.2.3. Dual CCK1/CCK2 receptor antagonists: Johnson \& Johnson identified compound $\mathbf{1 8 2}$ as a dual CCK1/CCK2 receptor antagonist with desirable pharmacologic properties [51,111113] (Figure 5). As can be seen from the structure of $\mathbf{1 8 2}$, 3-bromo-4-fluoro-L-phenylalanine $(\mathbf{6 5})$ is required for the synthesis.

5.2.4. Antidiabetes drugs, sitagliptin: $(R)-2,4,5$-Trifluorophenylalanine $\mathbf{3 8 b}$ is a constituent of sitagliptin (183, Figure 6). Sitagliptin is used to decrease the level of blood sugar<smiles>NC(Cc1ccc(B(O)O)cc1Br)C(=O)O</smiles>

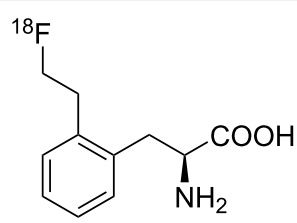

95<smiles>N[C@@H](Cc1ccc(OCC[18F])cc1)C(=O)O</smiles>

178

Figure 2: Structures of PET radiotracers of ${ }^{18} \mathrm{FPhe}$ derivatives. 
<smiles></smiles>

gastrazole (JB95008, 181)

Figure 4: Structure of gastrazole (JB95008, 181), a CCK2 receptor antagonist.<smiles>O=C(NC(Cc1ccc(F)c(Br)c1)C(=O)O)c1cc(Cl)c(Cl)cc1NS(=O)(=O)c1cccc2nsnc12</smiles>

182

Figure 5: Dual CCK1/CCK2 antagonist 182.

in patients with type 2 diabetes and belongs to the dipeptidyl peptidase-4 (DPP-4) class of inhibitors [114,115]. This enzyme breaks down the incretins GLP-1 and GIP, gastrointestinal hormones released in response to a meal. By preventing the breakdown of GLP-1 and GIP, they are able to increase the secretion of insulin by the pancreas that modulates blood sugar level when it is high. Sitagliptin was granted FDA approval in October, 2006 [116].<smiles>N[C@@H](CC(=O)N1CCn2c(nnc2C(F)(F)F)C1)Cc1cc(F)c(F)cc1F</smiles>

sitagliptin (183)

Figure 6: Structure of sitagliptin (183), an antidiabetic drug.

Retagliptin phosphate: Retagliptin phosphate (184) is under investigation as a DPP-4 inhibitor for treating type-2 diabetes. It is an analogue of sitagliptin which was developed for the same application [109,117], but compound $\mathbf{1 8 4}$ appears to have an improved activity [118]. Retagliptin showed efficacy in clinical trials and is now entering phase III studies. $(R)$-2,4,5-Trifluorophenylalanine $\mathbf{3 8 b}$ is used as a building block in the synthesis of compound 184 [119,120] (Figure 7).<smiles>CC(=O)c1nc(C(F)(F)F)n2c1CN(C(=O)C[C@@H](N)Cc1cc(F)c(F)cc1F)CC2</smiles>

Figure 7: Structure of retaglpitin (184) and antidiabetic drug.

Evogliptin: $(R)-2,4,5$-Trifluorophenylalanine $\mathbf{3 8 b}$ is required for the synthesis of evogliptin (185, Figure 8), an antidiabetic drug in the dipeptidyl peptidase-4 (DPP-4) inhibitor or "gliptin" class of drugs. The South Korean pharmaceutical company Dong-A ST developed evogliptin (185) and it is currently approved for use in South Korea [121-123].

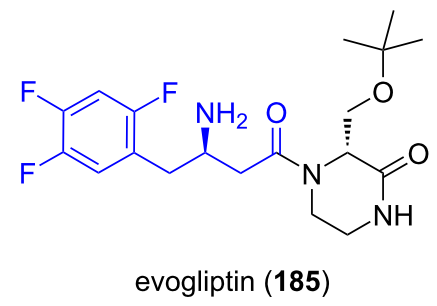

Figure 8: Structure of evogliptin (185), an antidiabetic drug.

LY2497282: Eli Lilly identified LY2497282 (186) as a potent and selective DPP-4 inhibitor, also for the treatment of type II diabetes. The inhibition of GLP-1 degradation by dipeptidyl peptidase IV (DPP-4) has emerged as a promising approach for treatment. (R)-2,5-Difluorophenylalanine is a required building block for the synthesis of LY2497282 [50,124] (Figure 9).<smiles>CC(C)(C)NC(=O)c1ccc(C(F)(F)F)cc1CC(O)[C@@H](N)Cc1cc(F)ccc1F</smiles>

Figure 9: Structure of LY2497282 (186) a DPP-4 inhibitor for the treatment of type II diabetes. 
5.2.5. Ulimorelin: Ulimorelin (187) is a small cyclic peptide containing D-4-FPhe. Ulimorelin acts as a selective agonist of the ghrelin/growth hormone secretagogue receptor (GHSR-1A), which is currently being developed by Tranzyme Pharma (code name TZP-101) as a first-in-class treatment for both, postoperative ileus (POI) and diabetic gastroparesis. POI describes a deceleration or arrest in intestinal motility following surgery [109,125-127] (Figure 10).

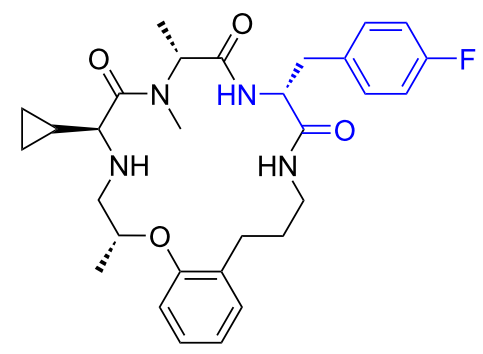

ulimorelin (187)

Figure 10: Structure of ulimorelin (187).

5.2.6. The glucagon-like peptide-1 receptor (GLP1R): 3 '-Fluorophenylalanine is a key motif in the structure of the glucagon-like peptide-1 receptor (GLP1R, 188, Figure 11) GLP1R is a receptor protein found on beta cells of the pancreas and on neurons of the brain. It is participating in the modulation of blood sugar levels by increasing insulin secretion. Consequently, GLP1R plays a key role in the development of drugs to treat diabetes mellitus [128-130].

5.2.7. Sodium channel blockers (benzazepinone Nav1.7 blocker): Sodium channel blockers are used in the treatment of neuropathic pain. This is a chronic, debilitating condition that results from injury of the peripheral or central nervous system and can be triggered by a variety of events or conditions, including diabetes, shingles and chemotherapy [131]. Merck reported [132] the discovery of a structurally novel class of benzazepinone hNav1.7 voltage-gated sodium channel blockers containing 2-trifluoromethoxy-L-phenylalanine derivative $\mathbf{1 8 9}$ and 3-L-FPhe 190 (Figure 12) [133]. Compounds 189 and 190 were investigated as potential drugs for the treatment of neuro- pathic pain because they inhibited action potential firing. It was suggested, based on genetic studies, that a selective Nav1.7 inhibition, will produce robust inhibition of pain without significant side effects $[134,135]$.<smiles>CC(C)N1C(=O)[C@H](NC(=O)[C@H](Cc2ccccc2OC(F)(F)F)NC(=O)OC(C)(C)C)CCc2ccccc21</smiles>

benzazepinone $\mathrm{Na}_{\mathrm{v}} 1.7$ blocker 189<smiles>CC(C)N1C(=O)[C@H](NC(=O)C(Cc2cccc(F)c2)NC(=O)OC(C)(C)C)CCc2ccccc21</smiles>

benzazepinone $\mathrm{Na}_{v} 1.7$ blocker 190

Figure 12: Structures of Nav1.7 blockers 189 and 190

\section{Conclusion}

In view of the increased significance of FAAs in the development of bioactive compounds, considerable efforts were dedicated to the development of efficient synthetic protocols to FAAs. Among them, a range of fluorinated phenylalanines emerged, that have enhanced the biophysical, chemical and biological properties of bioactives. Accordingly, synthetic approaches to five distinct classes of fluorinated analogues were reviewed here. Synthetic protocols and strategies varied according to the position of the fluorine substituent. Also included were ${ }^{18}$ FPhe derivatives, some of which emerged as promising radiotracers in positron emission tomography (PET). Finally, it is notable that there are a significant number of FPhe derivatives which are nowadays incorporated into drug scaffolds of compounds either licensed or currently being studied in clinical trials.<smiles>Cc1ccc(-c2ccc(C(=O)NC(Cc3ccc(-c4noc(-c5ccc(NC(=O)OCc6ccccc6)cc5)n4)c(F)c3)C(=O)O)o2)cc1</smiles>

Figure 11: Structure of GLP1R (188). 
Table 1: List of abbreviations.

\begin{tabular}{|c|c|}
\hline Ada & adamantyl \\
\hline Alloc & alloxycarbonyl \\
\hline BNCT & boron neutron capture therapy \\
\hline Boc & tert-butoxycarbonyl \\
\hline $\mathrm{Cbz}$ & benzyloxycarbonyl \\
\hline CCK & cholecystokinin \\
\hline DAST & diethylaminosulfur trifluoride \\
\hline DIBAL & diisobutylaluminium hydride \\
\hline DMB & dimethoxybenzyl \\
\hline DMAc & dimethylacetamide \\
\hline DPP-4 & dipeptidyl peptidase-4 \\
\hline DMPU & $N, N^{\prime}$-dimethylpropyleneurea \\
\hline FAAs & fluorinated amino acids \\
\hline FPhe & fluorinated phenylalanine \\
\hline Fmoc-Osu & $N$-(9-fluorenylmethoxycarbonyloxy)succinimide \\
\hline GLP1R & glucagon-like peptide-1 receptor \\
\hline kryptofix ${ }^{\circledR 222}$ & 4,7,13,16,21,24-hexaoxa-1,10-diazabicyclo[8.8.8]hexacosane \\
\hline LAT1 & L-type amino acid transporter1 \\
\hline LHMDS & lithium bis(trimethylsilyl)amide \\
\hline LDA & lithium diisopropylamide \\
\hline NaHDMS & sodium bis(trimethylsilyl)amide \\
\hline NFSI & $N$-fluorobenzenesulfonimide \\
\hline PAM & phenylalanine aminomutase \\
\hline PET & positron emission tomography \\
\hline PIP & 2-(pyridin-2-yl)isopropylamine \\
\hline Phth & phthalimido \\
\hline RRMM & relapsed and refractory multiple myeloma \\
\hline Selectfluor & 1-chloromethyl-4-fluoro-1,4-diazoniabicyclo[2.2.2]octane bis(tetrafluoroborate) \\
\hline SPhos & 2-dicyclohexylphosphino-2',6'-dimethoxybiphenyl \\
\hline TBAF & tetrabutylammonium fluoride \\
\hline TMSI & trimethylsilyl iodide \\
\hline TMSCN & trimethylsilyl cyanide \\
\hline TCE & trichloroethyl \\
\hline TCB & 1,2,4,5-tetracyanobenzene \\
\hline $\operatorname{Tr}$ & triphenylmethyl \\
\hline TEMPO & 2,2,6,6-tetramethylpiperidin-1-yl)oxyl or (2,2,6,6-tetramethylpiperidin-1-yl)oxidanyl \\
\hline TBTA & tert-butyl-2,2,2-trichloroacetimidate \\
\hline TCNHPI & $N$-hydroxytetrachlorophthalimide \\
\hline XtalFluor-E & $N, N$-diethylamino-S,S-difluorosulfinium tetrafluoroborate \\
\hline
\end{tabular}

\section{Acknowledgements}

L.F.A and M.S.A express sincere gratitude to Prof David

O'Hagan for his support, also we are grateful to Faculty of

Science, Alexandria University, Egypt.

\section{ORCID ${ }^{\circledR}$ iDs}

Laila F. Awad - https://orcid.org/0000-0001-9521-5511 Mohammed Salah Ayoup - https://orcid.org/0000-0001-6715-5478

\section{References}

1. Remete, A. M.; Nonn, M.; Fustero, S.; Fülöp, F.; Kiss, L. Tetrahedron 2018, 74, 6367-6418. doi:10.1016/j.tet.2018.09.021

2. Salwiczek, M.; Nyakatura, E. K.; Gerling, U. I. M.; Ye, S.; Koksch, B. Chem. Soc. Rev. 2012, 41, 2135-2171. doi:10.1039/c1cs15241f

3. Merkel, L.; Budisa, N. Org. Biomol. Chem. 2012, 10, 7241-7261. doi:10.1039/c2ob06922a

4. Purser, S.; Moore, P. R.; Swallow, S.; Gouverneur, V. Chem. Soc. Rev. 2008, 37, 320-330. doi:10.1039/b610213c 
5. Odar, C.; Winkler, M.; Wiltschi, B. Biotechnol. J. 2015, 10, 427-446. doi:10.1002/biot.201400587

6. Gómez-Nuñez, M.; Haro, K. J.; Dao, T.; Chau, D.; Won, A.; Escobar-Alvarez, S.; Zakhaleva, V.; Korontsvit, T.; Gin, D. Y.; Scheinberg, D. A. PLoS One 2008, 3, e3938. doi:10.1371/journal.pone.0003938

7. Noren, C.; Anthony-Cahill, S.; Griffith, M.; Schultz, P. Science 1989, 244, 182-188. doi:10.1126/science.2649980

8. Ye, S.; Berger, A. A.; Petzold, D.; Reimann, O.; Matt, B.; Koksch, B. Beilstein J. Org. Chem. 2010, 6, No. 40. doi:10.3762/bjoc.6.40

9. Tang, Y.; Ghirlanda, G.; Petka, W. A.; Nakajima, T.; DeGrado, W. F.; Tirrell, D. A. Angew. Chem., Int. Ed. 2001, 40, 1494-1496. doi:10.1002/1521-3773(20010417)40:8<1494::aid-anie1494>3.0.co;2$x$

10. Bilgiçer, B.; Fichera, A.; Kumar, K. J. Am. Chem. Soc. 2001, 123, 4393-4399. doi:10.1021/ja002961j

11. Kohlmann, J.; Braun, T.; Laubenstein, R.; Herrmann, R. Chem. - Eur. J. 2017, 23, 12218-12232. doi:10.1002/chem.201700549

12. Hoffmann, W.; Langenhan, J.; Huhmann, S.; Moschner, J.; Chang, R.; Accorsi, M.; Seo, J.; Rademann, J.; Meijer, G.; Koksch, B.; Bowers, M. T.; von Helden, G.; Pagel, K. Angew. Chem., Int. Ed. 2019, 58, 8216-8220. doi:10.1002/anie.201813954

13. Firooznia, F.; Gude, C.; Chan, K.; Fink, C. A.; Qiao, Y.; Satoh, Y.; Marcopoulos, N.; Savage, P.; Beil, M. E.; Bruseo, C. W.; Trapani, A. J.; Jeng, A. Y. Bioorg. Med. Chem. Lett. 2001, 11, 375-378. doi:10.1016/s0960-894x(00)00657-0

14. Lee, K.-H.; Lee, H.-Y.; Slutsky, M. M.; Anderson, J. T.; Marsh, E. N. G. Biochemistry 2004, 43, 16277-16284. doi:10.1021/bi049086p

15. Jäckel, C.; Koksch, B. Eur. J. Org. Chem. 2005, 4483-4503. doi:10.1002/ejoc.200500205

16. Jäckel, C.; Salwiczek, M.; Koksch, B. Angew. Chem., Int. Ed. 2006, 45, 4198-4203. doi:10.1002/anie.200504387

17. Salwiczek, M.; Samsonov, S.; Vagt, T.; Nyakatura, E.; Fleige, E.; Numata, J.; Cölfen, H.; Pisabarro, M. T.; Koksch, B. Chem. - Eur. J. 2009, 15, 7628-7636. doi:10.1002/chem.200802136

18. Budisa, N.; Wenger, W.; Wiltschi, B. Mol. BioSyst. 2010, 6, 1630-1639. doi:10.1039/c002256j

19. He, T.; Gershenson, A.; Eyles, S. J.; Lee, Y.-J.; Liu, W. R.; Wang, J.; Gao, J.; Roberts, M. F. J. Biol. Chem. 2015, 290, 19334-19342. doi:10.1074/jbc.m115.668343

20. Hammill, J. T.; Miyake-Stoner, S.; Hazen, J. L.; Jackson, J. C.; Mehl, R. A. Nat. Protoc. 2007, 2, 2601-2607. doi:10.1038/nprot.2007.379

21. Jackson, J. C.; Hammill, J. T.; Mehl, R. A. J. Am. Chem. Soc. 2007, 129, 1160-1166. doi:10.1021/ja064661t

22. Wiltschi, B. Expressed Protein Modifications: Making Synthetic Proteins. In Synthetic Gene Networks: Methods and Protocols; Weber, W.; Fussenegger, M., Eds.; Humana Press: Totowa, NJ, USA, 2012; pp 211-225. doi:10.1007/978-1-61779-412-4_13

23. Furter, R. Protein Sci. 1998, 7, 419-426. doi:10.1002/pro.5560070223

24. Munier, R.; Cohen, G. N. Biochim. Biophys. Acta 1959, 31, 378-391. doi:10.1016/0006-3002(59)90011-3

25. Moschner, J.; Stulberg, V.; Fernandes, R.; Huhmann, S.; Leppkes, J.; Koksch, B. Chem. Rev. 2019, 119, 10718-10801. doi:10.1021/acs.chemrev.9b00024

26. Andra, K. K. Biochem. Anal. Biochem. 2015, 4, No. 1000235. doi:10.4172/2161-1009.1000235
27. Mallareddy, J. R.; Tóth, G.; Fazakas, C.; Molnár, J.; Nagyőszi, P.; Lipkowski, A. W.; Krizbai, I. A.; Wilhelm, I. Chem. Biol. Drug Des. 2012, 79, 507-513. doi:10.1111/j.1747-0285.2011.01306.x

28. Mallareddy, J. R.; Borics, A.; Keresztes, A.; Kövér, K. E.; Tourwé, D.; Tóth, G. J. Med. Chem. 2011, 54, 1462-1472. doi:10.1021/jm101515v

29. Piepenbrink, K. H.; Borbulevych, O. Y.; Sommese, R. F.; Clemens, J.; Armstrong, K. M.; Desmond, C.; Do, P.; Baker, B. M. Biochem. J. 2009, 423, 353-361. doi:10.1042/bj20090732

30. Doubrovina, E. S.; Doubrovin, M. M.; Lee, S.; Shieh, J.-H.; Heller, G.; Pamer, E.; O'Reilly, R. J. Clin. Cancer Res. 2004, 10, 7207-7219. doi:10.1158/1078-0432.ccr-04-1040

31. Dominguez, M. A., Jr.; Thornton, K. C.; Melendez, M. G.; Dupureur, C. M. Proteins: Struct., Funct., Genet. 2001, 45, 55-61. doi:10.1002/prot.1123

32. Pace, C. J.; Gao, J. Acc. Chem. Res. 2013, 46, 907-915. doi:10.1021/ar300086n

33. Dougherty, D. A. Acc. Chem. Res. 2013, 46, 885-893. doi:10.1021/ar300265y

34. Oswald, C. L.; Carrillo-Márquez, T.; Caggiano, L.; Jackson, R. F. W. Tetrahedron 2008, 64, 681-687. doi:10.1016/j.tet.2007.11.031

35. Jackson, R. F. W.; Moore, R. J.; Dexter, C. S.; Elliott, J.; Mowbray, C. E. J. Org. Chem. 1998, 63, 7875-7884. doi:10.1021/jo981133u

36. Ross, A. J.; Lang, H. L.; Jackson, R. F. W. J. Org. Chem. 2010, 75, 245-248. doi:10.1021/j0902238n

37. Ayoup, M. S.; Cordes, D. B.; Slawin, A. M. Z.; O'Hagan, D. Org. Biomol. Chem. 2015, 13, 5621-5624. doi:10.1039/c5ob00650c

38. Ayoup, M. S.; Cordes, D. B.; Slawin, A. M. Z.; O'Hagan, D. Beilstein J. Org. Chem. 2015, 11, 2671-2676. doi:10.3762/bjoc.11.287

39. Liu, S.; Dockendorff, C.; Taylor, S. D. Org. Lett. 2001, 3, 1571-1574. doi:10.1021/ol0158664

40. Hill, B.; Ahmed, V.; Bates, D.; Taylor, S. D. J. Org. Chem. 2006, 71, 8190-8197. doi:10.1021/jo061496r

41. Bosshard, H. R.; Berger, A. Helv. Chim. Acta 1973, 56, 1838-1845. doi:10.1002/hlca.19730560603

42. Zheng, H.; Comeforo, K.; Gao, J. J. Am. Chem. Soc. 2009, 131, 18-19. doi:10.1021/ja8062309

43. Li, X.; Xiao, W.; He, G.; Zheng, W.; Yu, N.; Tan, M. Colloids Surf., $A$ 2012, 408, 79-86. doi:10.1016/j.colsurfa.2012.05.034

44. Kim, D.; Wang, L.; Beconi, M.; Eiermann, G. J.; Fisher, M. H.; He, H.; Hickey, G. J.; Kowalchick, J. E.; Leiting, B.; Lyons, K.; Marsilio, F.; McCann, M. E.; Patel, R. A.; Petrov, A.; Scapin, G.; Patel, S. B.; Roy, R. S.; Wu, J. K.; Wyvratt, M. J.; Zhang, B. B.; Zhu, L.; Thornberry, N. A.; Weber, A. E. J. Med. Chem. 2005, 48, 141-151. doi:10.1021/jm0493156

45. Setty, S. C.; Horam, S.; Pasupuleti, M.; Haq, W. Int. J. Pept. Res. Ther. 2017, 23, 213-225. doi:10.1007/s10989-016-9553-5

46. Castillo Meleán, J.; Ermert, J.; Coenen, H. H. Org. Biomol. Chem. 2011, 9, 765-769. doi:10.1039/c0ob00440e

47. Vukelić, S.; Ushakov, D. B.; Gilmore, K.; Koksch, B.; Seeberger, P. H. Eur. J. Org. Chem. 2015, 3036-3039. doi:10.1002/ejoc.201500300

48. Samet, A. V.; Coughlin, D. J.; Buchanan, A. C., III; Gakh, A. A. Synth. Commun. 2002, 32, 941-946. doi:10.1081/scc-120002709

49. FILLER, R.; NOVAR, H. J. Org. Chem. 1960, 25, 733-736. doi:10.1021/jo01075a015

50. Yu, H.; Richey, R. N.; Stout, J. R.; LaPack, M. A.; Gu, R.; Khau, V. V.; Frank, S. A.; Ott, J. P.; Miller, R. D.; Carr, M. A.; Zhang, T. Y. Org. Process Res. Dev. 2008, 12, 218-225. doi:10.1021/op700235c 
51. Liu, J.; Deng, X.; Fitzgerald, A. E.; Sales, Z. S.; Venkatesan, H.; Mani, N. S. Org. Biomol. Chem. 2011, 9, 2654-2660. doi:10.1039/c0ob01004a

52. Coenen, H. H.; Franken, K.; Kling, P.; Stöcklin, G. Int. J. Radiat. Appl. Instrum., Part A 1988, 39, 1243-1250. doi:10.1016/0883-2889(88)90107-4

53. Ishiwata, K.; Ido, T.; Mejia, A. A.; Ichihashi, M.; Mishima, Y. Int. J. Radiat. Appl. Instrum., Part A 1991, 42, 325-328. doi:10.1016/0883-2889(91)90133-I

54. Makaravage, K. J.; Brooks, A. F.; Mossine, A. V.; Sanford, M. S.; Scott, P. J. H. Org. Lett. 2016, 18, 5440-5443. doi:10.1021/acs.orglett.6b02911

55. Geurink, P. P.; Liu, N.; Spaans, M. P.; Downey, S. L.; van den Nieuwendijk, A. M. C. H.; van der Marel, G. A.; Kisselev, A. F.; Florea, B. I.; Overkleeft, H. S. J. Med. Chem. 2010, 53, 2319-2323. doi:10.1021/jm9015685

56. Chiu, H.-P.; Suzuki, Y.; Gullickson, D.; Ahmad, R.; Kokona, B.; Fairman, R.; Cheng, R. P. J. Am. Chem. Soc. 2006, 128, 15556-15557. doi:10.1021/ja0640445

57. Panella, L.; Aleixandre, A. M.; Kruidhof, G. J.; Robertus, J.; Feringa, B. L.; de Vries, J. G.; Minnaard, A. J. J. Org. Chem. 2006, 71, 2026-2036. doi:10.1021/jo052451d

58. Verhoeven, J.; Hulpia, F.; Kersemans, K.; Bolcaen, J.; De Lombaerde, S.; Goeman, J.; Descamps, B.; Hallaert, G.; Van den Broecke, C.; Deblaere, K.; Vanhove, C.; Van der Eycken, J.; Van Calenbergh, S.; Goethals, I.; De Vos, F. Sci. Rep. 2019, 9, 2878. doi:10.1038/s41598-019-40013-x

59. Ando, M.; Kuzuhara, H. Bull. Chem. Soc. Jpn. 1990, 63, 1925-1928. doi:10.1246/bcsj.63.1925

60. Kukhar, V. P.; Belokon, Y. N.; Soloshonok, V.; Svistunova, N. Yu.; Rozhenko, A. B.; Kuz'mina, N. A. Synthesis 1993, 117-120. doi:10.1055/s-1993-25812

61. Soloshonok, V. A.; Belokon', Yu. N.; Kukhar', V. P.; Chernoglazova, N. I.; Saporovskaya, M. B.; Bakhmutov, V. I.; Kolycheva, M. T.; Belikov, V. M. Russ. Chem. Bull. 1990, 39, 1479-1485. doi:10.1007/bf00957865

62. Drouet, F.; Noisier, A. F. M.; Harris, C. S.; Furkert, D. P.; Brimble, M. A. Eur. J. Org. Chem. 2014, 1195-1201. doi:10.1002/ejoc.201301718

63. Szymanski, W.; Wu, B.; Weiner, B.; de Wildeman, S.; Feringa, B. L.; Janssen, D. B. J. Org. Chem. 2009, 74, 9152-9157. doi:10.1021/jo901833y

64. Okuda, K.; Hirota, T.; Kingery, D. A.; Nagasawa, H. J. Org. Chem. 2009, 74, 2609-2612. doi:10.1021/j0802611t

65. Davis, F. A.; Srirajan, V.; Titus, D. D. J. Org. Chem. 1999, 64, 6931-6934. doi:10.1021/j0990947n

66. Shi, G.-q.; Zhao, Z.-y.; Zhang, X.-b. J. Org. Chem. 1995, 60 , 6608-6611. doi:10.1021/j000125a060

67. Kollonitsch, J.; Marburg, S.; Perkins, L. J. Org. Chem. 1975, 40 3808-3809. doi:10.1021/jo00913a900

68. Tsushima, T.; Kawada, K.; Nishikawa, J.; Sato, T.; Tori, K.; Tsuji, T.; Misaki, S. J. Org. Chem. 1984, 49, 1163-1169. doi:10.1021/jo00181a003

69. Tsushima, T.; Sato, T.; Tsuji, T. Tetrahedron Lett. 1980, 21, 3591-3592. doi:10.1016/0040-4039(80)80243-7

70. Wade, T. N.; Gaymard, F.; Guedj, R. Tetrahedron Lett. 1979, 20 , 2681-2682. doi:10.1016/s0040-4039(01)86385-1

71. Bloom, S.; McCann, M.; Lectka, T. Org. Lett. 2014, 16, 6338-6341. doi:10.1021/ol503094m
72. Egami, H.; Masuda, S.; Kawato, Y.; Hamashima, Y. Org. Lett. 2018, 20, 1367-1370. doi:10.1021/acs.orglett.8b00133

73. Bume, D. D.; Pitts, C. R.; Jokhai, R. T.; Lectka, T. Tetrahedron 2016, 72, 6031-6036. doi:10.1016/j.tet.2016.08.018

74. Davies, S. G.; Fletcher, A. M.; Frost, A. B.; Roberts, P. M.; Thomson, J. E. Org. Lett. 2015, 17, 2254-2257. doi:10.1021/acs.orglett.5b00880

75. Davies, S. G.; Fletcher, A. M.; Frost, A. B.; Roberts, P. M.; Thomson, J. E. Tetrahedron 2014, 70, 5849-5862. doi:10.1016/j.tet.2014.06.057

76. Davies, S. G.; Fletcher, A. M.; Frost, A. B.; Lee, J. A.; Roberts, P. M.; Thomson, J. E. Tetrahedron 2013, 69, 8885-8898. doi:10.1016/j.tet.2013.08.007

77. Zhang, Q.; Yin, X.-S.; Chen, K.; Zhang, S.-Q.; Shi, B.-F. J. Am. Chem. Soc. 2015, 137, 8219-8226. doi:10.1021/jacs.5b03989

78. Zhu, R.-Y.; Tanaka, K.; Li, G.-C.; He, J.; Fu, H.-Y.; Li, S.-H.; Yu, J.-Q. J. Am. Chem. Soc. 2015, 137, 7067-7070. doi:10.1021/jacs.5b04088

79. Meyer, S. D.; Schreiber, S. L. J. Org. Chem. 1994, 59, 7549-7552. doi:10.1021/jo00103a067

80. Dess, D. B.; Martin, J. C. J. Org. Chem. 1983, 48, 4155-4156. doi:10.1021/jo00170a070

81. Schlosser, M.; Brügger, N.; Schmidt, W.; Amrhein, N. Tetrahedron 2004, 60, 7731-7742. doi:10.1016/j.tet.2004.06.086

82. Harada, K.; Fox, S. W. Naturwissenschaften 1964, 51, 106-107. doi:10.1007/bf00629604

83. Schlosser, M. The Chemical and Physiological size of Fluorine. In Enantiocontrolled Synthesis of Fluoro-organic Compounds: Stereochemical Challenges and Biomedicinal Targets; Soloshonok, V. A., Ed.; John Wiley \& Sons: Chichester, UK, 1999; pp 613-659.

84. Wei, Q.; Ma, Y.; Li, L.; Liu, Q.; Liu, Z.; Liu, G. Org. Lett. 2018, 20 , 7100-7103. doi:10.1021/acs.orglett.8b03044

85. Vandenberghe, S.; Marsden, P. K. Phys. Med. Biol. 2015, 60, R115-R154. doi:10.1088/0031-9155/60/4/r115

86. Martarello, L.; Schaffrath, C.; Deng, H.; Gee, A. D.; Lockhart, A.; O'Hagan, D. J. Labelled Compd. Radiopharm. 2003, 46, 1181-1189. doi:10.1002/jlcr.779

87. Deng, H.; Cobb, S. L.; Gee, A. D.; Lockhart, A.; Martarello, L.; McGlinchey, R. P.; O'Hagan, D.; Onega, M. Chem. Commun. 2006, 652-654. doi:10.1039/b516861a

88. Snyder, H. R.; Reedy, A. J.; Lennarz, W. J. J. Am. Chem. Soc. 1958, 80, 835-838. doi:10.1021/ja01537a021

89. Ishiwata, K.; Ido, T.; Kawamura, M.; Kubota, K.; Ichihashi, M.; Mishima, Y. Int. J. Radiat. Appl. Instrum., Part B 1991, 18, 745-751. doi:10.1016/0883-2897(91)90013-b

90. Ishiwata, K. Ann. Nucl. Med. 2019, 33, 223-236. doi:10.1007/s12149-019-01347-8

91. Ishiwata, K.; Ido, T.; Honda, C.; Kawamura, M.; Ichihashi, M.; Mishima, Y. Int. J. Radiat. Appl. Instrum., Part B 1992, 19, 311-318. doi:10.1016/0883-2897(92)90116-g

92. Chandra, S.; Kabalka, G. W.; Lorey, D. R.; Smith, D. R.; Coderre, J. A. Clin. Cancer Res. 2002, 8, 2675-2683.

93. Tscherpel, C.; Dunkl, V.; Ceccon, G.; Stoffels, G.; Judov, N.; Rapp, M.; Meyer, P. T.; Kops, E. R.; Ermert, J.; Fink, G. R.; Shah, N. J.; Langen, K.-J.; Galldiks, N. Neuro-Oncology (Cary, NC, U. S.) 2017, 19, 710-718. doi:10.1093/neuonc/now243 
94. Verhoeven, J.; Bolcaen, J.; Kersemans, K.; De Meulenaere, V.; Deblaere, K.; Kalala, J.; Van den Broecke, C.; Vanhove, C.; Goethals, I.; De Vos, F. Neuro-Oncology (Cary, NC, U. S.) 2017, 19 (Suppl. 3), iii46. doi:10.1093/neuonc/nox036.166

95. Chiaravalloti, A.; Filippi, L.; Ricci, M.; Cimini, A.; Schillaci, O. Cancers 2019, 11, 1853. doi:10.3390/cancers11121853

96. Moreau, A.; Febvey, O.; Mognetti, T.; Frappaz, D.; Kryza, D. Front. Oncol. 2019, 9, No. 1134. doi:10.3389/fonc.2019.01134

97. Lahoutte, T.; Caveliers, V.; Camargo, S. M.; Franca, R.; Ramadan, T.; Veljkovic, E.; Mertens, J.; Bossuyt, A.; Verrey, F. J. Nucl. Med. 2004, 45, 1591-1596.

98. Bolcaen, J.; Descamps, B.; Deblaere, K.; Boterberg, T.; De Vos Pharm, F.; Kalala, J.-P.; Van den Broecke, C.; Decrock, E.; Leybaert, L.; Vanhove, C.; Goethals, I. Nucl. Med. Biol. 2015, 42, 38-45. doi:10.1016/j.nucmedbio.2014.07.006

99. Feral, C. C.; Tissot, F. S.; Tosello, L.; Fakhry, N.; Sebag, F.; Pacak, K.; Taïeb, D. Eur. J. Nucl. Med. Mol. Imaging 2017, 44, 812-821. doi:10.1007/s00259-016-3586-z

100.Sun, A.; Liu, X.; Tang, G. Front. Chem. (Lausanne, Switz.) 2018, 5, No. 124. doi:10.3389/fchem.2017.00124

101.Chiotellis, A.; Müller Herde, A.; Rössler, S. L.; Brekalo, A.; Gedeonova, E.; Mu, L.; Keller, C.; Schibli, R.; Krämer, S. D.; Ametamey, S. M. J. Med. Chem. 2016, 59, 5324-5340. doi:10.1021/acs.jmedchem.6b00057

102. Strese, S. Anticancer Activity of Melflufen: Preclinical Studies of a Novel Peptidase-Potentiated Alkylator; Acta Universitatis Upsaliensis, 2015.

103.Carlier, C.; Strese, S.; Viktorsson, K.; Velander, E.; Nygren, P.; Uustalu, M.; Juntti, T.; Lewensohn, R.; Larsson, R.; Spira, J.; De Vlieghere, E.; Ceelen, W. P.; Gullbo, J. Oncotarget 2016, 7, 59322-59335. doi:10.18632/oncotarget.11163

104. Ormerod, D.; Willemsens, B.; Mermans, R.; Langens, J.; Winderickx, G.; Kalindjian, S. B.; Buck, I. M.; McDonald, I. M. Org. Process Res. Dev. 2005, 9, 499-507. doi:10.1021/op0500638

105. Chau, I.; Cunningham, D.; Russell, C.; Norman, A. R.; Kurzawinski, T.; Harper, P.; Harrison, P.; Middleton, G.; Daniels, F.; Hickish, T.; Prendeville, J.; Ross, P. J.; Theis, B.; Hull, R.; Walker, M.; Shankley, N.; Kalindjian, B.; Murray, G.; Gillbanks, A.; Black, J. Br. J. Cancer 2006, 94, 1107-1115. doi:10.1038/sj.bjc.6603058

106. Harper, E. A.; Roberts, S. P.; Kalindjian, S. B. Br. J. Pharmacol. 2007, 151, 1352-1367. doi:10.1038/sj.bjp.0707355

107.McDonald, I. M.; Black, J. W.; Buck, I. M.; Dunstone, D. J.; Griffin, E. P.; Harper, E. A.; Hull, R. A. D.; Kalindjian, S. B.; Lilley, E. J.; Linney, I. D.; Pether, M. J.; Roberts, S. P.; Shaxted, M. E.; Spencer, J.; Steel, K. I. M.; Sykes, D. A.; Walker, M. K.; Watt, G. F.; Wright, L.; Wright, P. T.; Xun, W. J. Med. Chem. 2007, 50, 3101-3112. doi:10.1021/jm070139l

108. Harper, E. A.; Mitchell, E. A.; Griffin, E. P.; Kalindjian, S. B. Eur. J. Pharmacol. 2008, 581, 1-12. doi:10.1016/j.ejphar.2007.11.055

109. Mei, H.; Han, J.; Klika, K. D.; Izawa, K.; Sato, T.; Meanwell, N. A.; Soloshonok, V. A. Eur. J. Med. Chem. 2020, 186, 111826. doi:10.1016/j.ejmech.2019.111826

110.Roberts, S.; Griffin, E.; Harper, E.; Hull, R; Kalindjian, S.; Lilley, E.; Kotecha, A.; Shankley, N.; Sykes, D.; Watt, G. Pharmacologist 2002, 44 (Suppl. 1), 30.

111. Herranz, R. Med. Res. Rev. 2003, 23, 559-605. doi:10.1002/med.10042

112.Berna, M. J.; Tapia, J. A.; Sancho, V.; Jensen, R. T. Curr. Opin. Pharmacol. 2007, 7, 583-592. doi:10.1016/j.coph.2007.09.011
113.Pippel, M.; Boyce, K.; Venkatesan, H.; Phuong, V. K.; Yan, W.; Barrett, T. D.; Lagaud, G.; Li, L.; Morton, M. F.; Prendergast, C.; Wu, X.; Shankley, N. P.; Rabinowitz, M. H. Bioorg. Med. Chem. Lett. 2009, 19, 6376-6378. doi:10.1016/j.bmcl.2009.09.065

114. Herman, G. A.; Stevens, C.; Van Dyck, K.; Bergman, A.; Yi, B.; De Smet, M.; Snyder, K.; Hilliard, D.; Tanen, M.; Tanaka, W.; Wang, A. Q.; Zeng, W.; Musson, D.; Winchell, G.; Davies, M. J.; Ramael, S.; Gottesdiener, K. M.; Wagner, J. A. Clin. Pharmacol. Ther. (Hoboken, NJ, U. S.) 2005, 78, 675-688. doi:10.1016/j.clpt.2005.09.002

115. Kushwaha, R. N.; Haq, W.; Katti, S. Chem. Biol. Interface 2014, 4 , 137-162.

116.Baksh, S. N.; McAdams-DeMarco, M.; Segal, J. B.; Alexander, G. C. Pharmacoepidemiol. Drug Saf. 2018, 27, 660-667. doi:10.1002/pds.4437

117. Kaihong, Y.; Piaoyang, S. Pharmaceutical composition for treatment of type 2 diabetes. U.S. Patent US 8,476,272 B2, July 2, 2013.

118. Drugbank, Retagliptin. https://www.drugbank.ca/drugs/DB14898 (accessed Feb 25, 2020).

119. Notte, G. T. Annu. Rep. Med. Chem. 2014, 49, 417-436. doi:10.1016/b978-0-12-800167-7.00026-2

120. Yong, X.; Hu, T.; Feng, S.; Du, X.; Shi, H.; Feng, W. Trop. J. Pharm. Res. 2015, 14, 1481-1486. doi:10.4314/tjpr.v14i8.22 121. McCormack, P. L. Drugs 2015, 75, 2045-2049. doi:10.1007/s40265-015-0496-5

122. Flick, A. C.; Ding, H. X.; Leverett, C. A.; Kyne, R. E., Jr.; Liu, K. K.-C.; Fink, S. J.; O'Donnell, C. J. J. Med. Chem. 2017, 60, 6480-6515. doi:10.1021/acs.jmedchem.7b00010

123. Oh, J.; Kim, A. H.; Lee, S.; Cho, H.; Kim, Y. S.; Bahng, M. Y.; Yoon, S. H.; Cho, J.-Y.; Jang, I.-J.; Yu, K.-S. Diabetes Obes. Metab. 2017, 19, 294-298. doi:10.1111/dom.12813

124.Zhao, W. Handbook for Chemical Process Research and Development; CRC Press: Boca Raton, FL, USA, 2016. doi:10.1201/9781315367316

125. Fraser, G. L.; Hoveyda, H. R.; Tannenbaum, G. S. Endocrinology 2008, 149, 6280-6288. doi:10.1210/en.2008-0804

126. Lasseter, K. C.; Shaughnessy, L.; Cummings, D.; Pezzullo, J. C.; Wargin, W.; Gagnon, R.; Oliva, J.; Kosutic, G. J. Clin. Pharmacol. 2008, 48, 193-202. doi:10.1177/0091270007310380

127. Hoveyda, H. R.; Marsault, E.; Gagnon, R.; Mathieu, A. P.; Vézina, M.; Landry, A.; Wang, Z.; Benakli, K.; Beaubien, S.; Saint-Louis, C.; Brassard, M.; Pinault, J.-F.; Ouellet, L.; Bhat, S.; Ramaseshan, M.; Peng, X.; Foucher, L.; Beauchemin, S.; Bhérer, P.; Veber, D. F.; Peterson, M. L.; Fraser, G. L. J. Med. Chem. 2011, 54, 8305-8320. doi:10.1021/jm2007062

128. Gallwitz, B. Drugs 2011, 71, 1675-1688. doi:10.2165/11592810-000000000-00000

129. Trujillo, J. M.; Nuffer, W. Pharmacotherapy 2014, 34, 1174-1186. doi:10.1002/phar.1507

130. Gallwitz, B. Glucagon-like peptide-1 receptor agonists. In Handbook of Incretin-based Therapies in Type 2 Diabetes; Gough, S., Ed.; Springer International Publishing: Cham, Switzerland, 2016; pp 31-43. doi:10.1007/978-3-319-08982-9_3

131. Theile, J. W.; Cummins, T. R. Front. Pharmacol. 2011, 2, No. 54. doi:10.3389/fphar.2011.00054

132. Hoyt, S. B.; London, C.; Abbadie, C.; Felix, J. P.; Garcia, M. L.; Jochnowitz, N.; Karanam, B. V.; Li, X.; Lyons, K. A.; McGowan, E.; Priest, B. T.; Smith, M. M.; Warren, V. A.; Thomas-Fowlkes, B. S.; Kaczorowski, G. J.; Duffy, J. L. Bioorg. Med. Chem. Lett. 2013, 23, 3640-3645. doi:10.1016/j.bmcl.2013.03.121 
133. Hoyt Scott, B.; London, C.; Ok, D.; Parsons, W. H. Benzaepinones as sodium channel blockers. U.S. Patent US 7,888,345 B2, Feb 15, 2011.

134.Hoyt, S. B.; London, C.; Gorin, D.; Wyvratt, M. J.; Fisher, M. H.; Abbadie, C.; Felix, J. P.; Garcia, M. L.; Li, X.; Lyons, K. A.; McGowan, E.; MacIntyre, D. E.; Martin, W. J.; Priest, B. T.; Ritter, A.; Smith, M. M.; Warren, V. A.; Williams, B. S.; Kaczorowski, G. J.; Parsons, W. H. Bioorg. Med. Chem. Lett. 2007, 17, 4630-4634. doi:10.1016/j.bmcl.2007.05.076

135. Hoyt, S. B.; London, C.; Ok, H.; Gonzalez, E.; Duffy, J. L.; Abbadie, C.; Dean, B.; Felix, J. P.; Garcia, M. L.; Jochnowitz, N.; Karanam, B. V.; Li, X.; Lyons, K. A.; McGowan, E.; MacIntyre, D. E.; Martin, W. J.; Priest, B. T.; Smith, M. M.; Tschirret-Guth, R.; Warren, V. A.; Williams, B. S.; Kaczorowski, G. J.; Parsons, W. H. Bioorg. Med. Chem. Lett. 2007, 17, 6172-6177. doi:10.1016/j.bmcl.2007.09.032

\section{License and Terms}

This is an Open Access article under the terms of the Creative Commons Attribution License

(http://creativecommons.org/licenses/by/4.0). Please note that the reuse, redistribution and reproduction in particular requires that the authors and source are credited.

The license is subject to the Beilstein Journal of Organic Chemistry terms and conditions: (https://www.beilstein-journals.org/bjoc)

The definitive version of this article is the electronic one which can be found at: doi:10.3762/bjoc. 16.91 